\title{
Heteromeric $\mathrm{K}_{\mathrm{v}}$ 7.2/7.3 Channels Differentially Regulate Action Potential Initiation and Conduction in Neocortical Myelinated Axons
}

\author{
Arne Battefeld, ${ }^{1}$ Baouyen T. Tran, ${ }^{2}$ Jason Gavrilis, ${ }^{3,4}$ Edward C. Cooper, ${ }^{2}$ and Maarten H. P. Kole ${ }^{1,3}$ \\ ${ }^{1}$ Netherlands Institute for Neuroscience, Royal Academy of Arts and Sciences, 1105 BA, Amsterdam, The Netherlands, ${ }^{2}$ Baylor College of Medicine, Baylor \\ Plaza, Houston, Texas 77030, ${ }^{3}$ Eccles Institute for Neuroscience, The Australian National University, Canberra 0200, Australian Capital Territory, Australia, \\ and ${ }^{4}$ Department of Audiology and Speech Pathology, University of Melbourne, Melbourne, Victoria 3010, Australia
}

\begin{abstract}
Rapid energy-efficient signaling along vertebrate axons is achieved through intricate subcellular arrangements of voltage-gated ion channels and myelination. One recently appreciated example is the tight colocalization of $\mathrm{K}_{\mathrm{v}} 7$ potassium channels and voltage-gated sodium $\left(\mathrm{Na}_{\mathrm{v}}\right)$ channels in the axonal initial segment and nodes of Ranvier. The local biophysical properties of these $\mathrm{K}_{\mathrm{v}} 7$ channels and the functional impact of colocalization with $\mathrm{Na}_{\mathrm{v}}$ channels remain poorly understood. Here, we quantitatively examined $\mathrm{K}_{\mathrm{v}} 7$ channels in myelinated axons of rat neocortical pyramidal neurons using high-resolution confocal imaging and patch-clamp recording. $\mathrm{K}_{\mathrm{v}} 7.2$ and 7.3 immunoreactivity steeply increased within the distal two-thirds of the axon initial segment and was mirrored by the conductance density estimates, which increased from $\sim 12$ (proximal) to $150 \mathrm{pS} \mu \mathrm{m}^{-2}$ (distal). The axonal initial segment and nodal M-currents were similar in voltage dependence and kinetics, carried by $\mathrm{K}_{\mathrm{v}} 7.2 / 7.3$ heterotetramers, $4 \%$ activated at the resting membrane potential and rapidly activated with single-exponential time constants $(\sim 15 \mathrm{~ms}$ at $28 \mathrm{mV})$. Experiments and computational modeling showed that while somatodendritic $\mathrm{K}_{\mathrm{v}} 7$ channels are strongly activated by the backpropagating action potential to attenuate the afterdepolarization and repetitive firing, axonal $\mathrm{K}_{\mathrm{v}} 7$ channels are minimally recruited by the forward-propagating action potential. Instead, in nodal domains $\mathrm{K}_{\mathrm{v}}$ 7.2/7.3 channels were found to increase $\mathrm{Na}_{\mathrm{v}}$ channel availability and action potential amplitude by stabilizing the resting membrane potential. Thus, $\mathrm{K}_{\mathrm{v}} 7$ clustering near axonal $\mathrm{Na}_{\mathrm{v}}$ channels serves specific and context-dependent roles, both restraining initiation and enhancing conduction of the action potential.
\end{abstract}

Key words: axon; excitability; $\mathrm{K}_{\mathrm{v}} 7$

\section{Introduction}

Axon initial segments (AISs) and nodes of Ranvier are two fundamental specializations in axons of jawed vertebrates for the initiation and conduction of action potentials. These crucial functions are mediated by clustered subcellular expression of specific voltage-gated conductances (Poliak and Peles, 2003; Rasband, 2010; Kole and Stuart, 2012). The M-current $\left(I_{M}\right)$ is a noninactivating voltage-gated potassium $\left(\mathrm{K}_{\mathrm{v}}\right)$ current characterized

Received Oct. 1, 2013; revised Jan. 27, 2014; accepted Jan. 30, 2014.

Author contributions: E.C.C. and M.H.P.K. designed research; A.B., B.T.T., J.G., and M.H.P.K. performed research; E.C.C. and M.H.P.K. contributed unpublished reagents/analytic tools; A.B., B.T.T., J.G., E.C.C., and M.H.P.K. analyzed data; A.B., B.T.T., E.C.C., and M.H.P.K. wrote the paper.

This work was supported by the European Research Council (ERC) under the European Community's Seventh Framework Program (FP7/2007-2013)/ERC Grant agreement P261114, the Australian National Health and Medical Research Council (Project Grant \#525437) to M.H.P.K., and National Institutes of Health (NIH) Grant R01 NS49119 to E.C.C. B.T.T. is the recipient of an Epilepsy Foundation predoctoral fellowship funded by the American Epilepsy Society and the Pediatric Epilepsy Research Foundation. We thank S. de Vries for excellent technical support and S. Hallermann for critical reading of the manuscript. Ankyrin-G and Caspr monoclonal antibodies were developed by the University of California, Davis/NIH NeuroMab Facility (NIH Grant U24 NS050606).

Correspondence should be addressed to Dr. Maarten H. P. Kole, Netherlands Institute for Neuroscience, Royal Academy of Arts and Sciences, Meibergdreef 47, 1105 BA, Amsterdam, the Netherlands. E-mail: m.kole@nin.knaw.nl.

DOI:10.1523/JNEUROSCI.4206-13.2014

Copyright $\odot 2014$ the authors $\quad 0270-6474 / 14 / 343719-14 \$ 15.00 / 0$ by relatively slow kinetics, a low voltage threshold for activation and regulation by muscarinic receptors (Brown and Adams, 1980). In many neurons, $I_{\mathrm{M}}$ is carried by heteromultimeric combinations of $\mathrm{K}_{\mathrm{v}} 7.2$ and $\mathrm{K}_{\mathrm{v}} 7.3$ (also called KCNQ2/3) subunits (Wang et al., 1998). $\mathrm{K}_{\mathrm{v}} 7.2$ and $\mathrm{K}_{\mathrm{v}} 7.3$ are encoded by paralogous vertebrate genes that share a unique domain for binding to ankyrin $G$ and mediating their coclustering with voltage-gated sodium $\left(\mathrm{Na}_{\mathrm{v}}\right)$ channels to the AIS and nodes of Ranvier (Pan et al., 2006; Cooper, 2011). Loss-of-function mutations in $\mathrm{K}_{\mathrm{v}} 7.2$ and $\mathrm{K}_{\mathrm{v}} 7.3$ have been found to underlie a spectrum of neurological diseases including neonatal-onset epilepsy, myokymia, and epileptic encephalopathy (Biervert et al., 1998; Jentsch, 2000; Maljevic et al., 2008; Weckhuysen et al., 2012; Kato et al., 2013), highlighting the importance of their expression in these privileged excitable domains. Although inferences of axonal $\mathrm{K}_{\mathrm{v}} 7 \mathrm{chan}-$ nel function have been drawn from somatic and peripheral nerve recordings, the properties and function of $\mathrm{K}_{\mathrm{v}} 7.2 / 7.3$ channels intrinsic to axonal domains of central neurons have remained elusive.

Past research revealed two contrasting roles of axonal $\mathrm{K}_{\mathrm{v}} 7$ conductance. In hippocampal CA1 pyramidal neurons, competitive inhibition of $\mathrm{K}_{\mathrm{v}} 7.2 / 7.3$ binding to ankyrin $\mathrm{G}$, or bath application of XE-991, a highly selective $\mathrm{K}_{\mathrm{v}} 7$ blocker (Wang et al., 
1998), led to spontaneous action potentials and hyperpolarized the voltage threshold for action potential generation, suggesting an attenuating role of the AIS $\mathrm{K}_{\mathrm{v}} 7$ channel in excitability (Shah et al., 2008). In contrast, the application of XE-991 reduced both glutamate release and presynaptic fiber volley amplitude at Schaffer collateral synapses, suggesting that the presence of $I_{\mathrm{M}}$ in axons may facilitate axonal excitability (Vervaeke et al., 2006). $I_{\mathrm{M}}$-like currents (called $I_{\mathrm{Ks}}$ currents) have been isolated in recordings from single rat sciatic nerve nodes of Ranvier (Röper and Schwarz, 1989; Safronov et al., 1993; Schwarz et al., 2006) and from the calyx of Held presynaptic terminal (Huang and Trussell, 2008). These studies revealed a large $(20-50 \mathrm{mV})$ hyperpolarizing shift in the voltage dependence of activation, compared with the somatic $I_{\mathrm{M}}$ (Safronov et al., 1993; Huang and Trussell, 2011), raising the possibility that perisomatic and more distal axonal $\mathrm{K}_{\mathrm{v}} 7$ channels differ greatly.

Here, using whole-cell, cell-attached, and outside-out voltage-clamp recordings of $I_{\mathrm{M}}$ combined with high-resolution imaging of $\mathrm{K}_{\mathrm{v}} 7.2 /$ 7.3 immunofluorescence, we determined that axonal $I_{\mathrm{M}}$ is mediated by $\mathrm{K}_{\mathrm{v}} 7.2 / 7.3$ heterotetramers and exhibits pharmacological and biophysical properties similar to the somatic $I_{\mathrm{M}}$. Using simultaneous recordings from soma and axons combined with conductancebased computational modeling, we found that unlike the perisomatic region, where $\mathrm{K}_{\mathrm{v}} 7$ channel activation counteracts the persistent $\mathrm{Na}_{\mathrm{v}}$ current and restrains repetitive firing, in the node of Ranvier $\mathrm{K}_{\mathrm{v}} 7$ channels set the resting membrane conductance and augment the amplitude of the propagating presynaptic action potential.

\section{Materials and Methods}

Animals. All experiments were performed according to guidelines approved by the local animal ethics committees of the Royal Netherlands Academy of Arts and Sciences, Baylor College of Medicine, and the Australian National University. Adult male Wistar rats [postnatal day 28 (P28) to P91; Harlan Laboratories] were deeply anesthetized by $3 \%$ isoflurane (v/v) inhalation and subsequently decapitated; brain slices were then prepared as described previously (Kole et al., 2007).

Electrophysiological recordings. Individual slices were transferred to the stage of a Zeiss Axioskop or Olympus BX51WI microscope. The microscope bath was perfused with normal ACSF consisting of the following (in mM): $125 \mathrm{NaCl}, 25 \mathrm{NaHCO}_{3}, 3 \mathrm{KCl}, 1.25 \mathrm{NaH}_{2} \mathrm{PO}_{4}, 25$ glucose, 2 $\mathrm{CaCl}_{2}$, and $1 \mathrm{MgCl}_{2}$ saturated with $95 \% \mathrm{O}_{2} / 5 \% \mathrm{CO}_{2}$, $\mathrm{pH}$ 7.4. Currentclamp and voltage-clamp recordings from dendrites, soma, and cut axons were all made between 1 and $10 \mathrm{~h}$ after slice preparation. Dual whole-cell current-clamp recordings were made using Dagan BVC-700A amplifiers (Dagan). Patch pipettes were pulled from borosilicate glass (outer diameter, $1.5 \mathrm{~mm}$; inner diameter, $0.86 \mathrm{~mm}$ ) and had an open tip resistance of 5-7 M $\Omega$, filled with the following standard intracellular solution (in mM): $130 \mathrm{~K}^{+}$-gluconate, $10 \mathrm{KCl}, 4 \mathrm{Mg}^{2+}$-ATP, $0.3 \mathrm{Na}^{+}$GTP, 10 HEPES, and $10 \mathrm{Na}_{2}$-phosphocreatine, $\mathrm{pH} 7.3$ with $\mathrm{KOH}(\sim 280$ mOsm kg $\left.{ }^{-1}\right)$. Biocytin $(5 \mathrm{mg} / \mathrm{ml})$ and Alexa Fluor 488/594 (200 $\mu \mathrm{M}$; Life Technologies) were routinely added to the intracellular solution. Axonal recording distances were taken as linear estimations from the live brightfield or fluorescence images, or from the axonal path distances of reconstructed neurons filled with biocytin (Kole et al., 2007). Voltage was analog low-pass filtered at $10 \mathrm{kHz}$ (Bessel filter) and digitally sampled at 50 or $100 \mathrm{kHz}$ using an AD/DA converter (ITC-18, HEKA Elektronik $\mathrm{GmbH}$ ) and using the data acquisition software Axograph X (AxoGraph Scientific). The access resistance during current-clamp experiments ranged between 8 and $20 \mathrm{M} \Omega$ for somatic and axonal recordings, up to 30 $\mathrm{M} \Omega$ for dendritic recordings, and was fully compensated using bridge balance and capacitance neutralization of the amplifiers.

For whole-cell voltage-clamp recordings of $I_{\mathrm{M}}$, the extracellular ACSF was supplemented with $5 \mathrm{~mm}$ 4-aminopyridine (4-AP), $1 \mu \mathrm{M}$ tetrodotoxin (TTX), and $20 \mu \mathrm{M}$ 4-ethylphenylamino-1,2-dimethyl-6-methylaminopyrimidinium chloride (ZD-7288) to block the fast-activating $\mathrm{K}_{\mathrm{v}} 1, \mathrm{Na}_{\mathrm{v}}$, and hyperpolarization-activated cyclic nucleotide $(\mathrm{HCN})$-gated currents, re- spectively. Preliminary experiments showed that the addition of cadmium $\left(\mathrm{Cd}^{2+}\right)$, often used to block $\mathrm{Ca}^{2+}$ currents at more depolarized potentials, inhibited $I_{\mathrm{M}}$ amplitudes and slowed the rise time (see also Robbins et al., 1992), and was therefore omitted from the routine voltage-clamp solution. For cell-attached recordings of $\mathrm{K}^{+}$currents, we used patch-pipettes $(\sim 10 \mathrm{M} \Omega$ ) filled with the following (in $\mathrm{mm}$ ): $125 \mathrm{NaCl}, 2.5 \mathrm{KCl}, 20$ HEPES, 20 glucose, $2 \mathrm{MgCl}_{2}, 1 \mu \mathrm{M}$ TTX, and $5 \mathrm{~mm}$ 4-AP, pH 7.3 with $\mathrm{NaOH}(285 \mathrm{mOsm}) . \mathrm{CaCl}_{2}$ was omitted to increase the probability of M-channel opening (Selyanko and Brown, 1999; Selyanko et al., 2001). Voltage-clamp recordings were made with an Axopatch 200B or Multiclamp 700A amplifier (Molecular Devices), and currents were low-pass filtered at $4-10 \mathrm{kHz}$ (eight-pole Bessel filter) with $10-50 \mathrm{kHz}$ sampling frequencies. To subtract the capacitive and leak currents, the membrane patch or axon bleb was held at $-92 \mathrm{mV}$ and a $\mathrm{P} /-6$ leak subtraction protocol was applied on-line. In voltage-clamp configuration, the series resistance $\left(R_{\mathrm{s}}\right)$ was $\sim 14 \mathrm{M} \Omega$. Recordings with $\sim 90 \% R_{\mathrm{s}}$ compensation indicated that the current rise times and/or amplitudes were not different from those of uncompensated recordings ( $p=0.41$ and $p=0.27$, respectively; $n=4)$, which is consistent with the low peak amplitudes of the currents $(\sim 0.5 \mathrm{nA})$ and their slow kinetics $(>10 \mathrm{~ms}) . R_{\mathrm{s}}$ compensation was therefore not applied. Voltage values for whole-cell recordings were corrected for the calculated liquid junction potential (LJP) of $-12 \mathrm{mV}$ of the $\mathrm{K}^{+}$-gluconate intracellular solution. Direct recording of the LJP revealed a nearly similar value of $-13.5 \pm 0.2 \mathrm{mV}(n=3)$. All recordings were made at $35 \pm 1^{\circ} \mathrm{C}$, unless otherwise indicated.

All salt compounds, biocytin, 4-AP, and tetraethylammonium (TEA) were obtained from Sigma-Aldrich. Other drugs, including 10,10-bis(4pyridinylmethyl)-9(10H)-anthracenone dihydrochloride (XE-991), ZD-7288, [R- $\left.\left(R^{*}, S^{*}\right)\right]$-6-(5,6,7,8-tetrahydro-6-methyl-1,3-dioxolo[4,5$g$ ] isoquinolin-5-yl)furo[3, 4-e]-1,3-benzodioxol-8 $(6 H)$-one, 6-imino3-(4-methoxyphenyl)-1(6H)-pyridazinebutanoic acid hydrobromide (gabazine), 6,7-dinitroquinoxaline-2,3-dione (DNQX; $20 \mu \mathrm{M}), 2$ amino-6-trifluoromethoxybenzothia-zole hydrochloride (riluzole), and TTX were obtained from Tocris Bioscience. These were dissolved in distilled water, and aliquots were stored at $-20^{\circ} \mathrm{C}$. Retigabine (a gift from Sigrid Blom, Lundbeck, Valby, Denmark) was dissolved to $100 \mathrm{~mm}$ in dimethylsulfoxide and stocks stored at $-20^{\circ} \mathrm{C}$. Local applications of XE991 were made by diluting XE-991 in HEPES-buffered ACSF or in normal extracellular ACSF. Puffing solutions were loaded in a patch pipette ( $\sim 5 \mathrm{M} \Omega$ resistance) connected to a Picospritzer III system (Intracel). By adjusting the pressure $(\sim 1$ bar $)$, we aimed for a localized response of $\sim 50$ $\mu \mathrm{m}$ radius as determined from the bright-field image of the slice (Kole et al., 2007).

Analysis. We determined input resistance by the slope of linear fits to small $(<5 \mathrm{mV})$ voltage responses evoked by positive and negative current injections. To analyze the steady-state voltage dependence of $I_{\mathrm{M}}$, the current amplitudes were converted to conductance values $(G)$ for each step potential $(V)$, normalized to the maximum conductance $\left(G_{\max }\right)$, and fitted with a Boltzmann equation of the form; $y=1 /\left(1+\exp \left(-z \frac{\left(V-V_{\text {half }}\right)}{(R T / F)}\right)\right)$, in which $V_{\text {half }}$ is the half-maximum activation voltage, $z$ the effective valence. The thermodynamic gas constant $(R)$, temperature $(T)$, and Faraday's constant $(F)$ were implemented as a single constant of $26.55 \mathrm{mV}$ for recordings at $35^{\circ} \mathrm{C}$

The sensitivity of the axonal currents to XE-991 and TEA inhibition was analyzed by averaging the raw steady-state amplitudes for voltage steps between 10 and $40 \mathrm{mV}$, and normalizing the current amplitudes in the presence of the drug to the control amplitudes. Data were averaged over multiple cells and fit with a Hill equation of the following form:

$$
y=y_{0}+\left(y_{\max }-y_{0}\right) /\left(1+\left(\frac{x_{\text {half }}}{x}\right)^{n}\right),
$$

in which $y_{\mathrm{o}}$ is the unblocked current amplitude, $y_{\max }$ is the maximally blocked current amplitude, $x$ is the concentration, $x_{\text {half }}$ is the $\mathrm{IC}_{50}$, and $n$ is the power of the drug block, equivalent to the Hill slope. Fitting was performed in Igor Pro (version 5.05, WaveMetrics).

The kinetic description of the axonal M-current followed the classic formalism of Hodgkin and Huxley (1952). Since $I_{\mathrm{M}}$ does not inactivate the relationship between the channel conductance and the current, it can 
be defined as follows: $I_{M}=\bar{g}_{M} n\left(V-E_{K}\right)$. In this equation, $\bar{g}_{M}$ is the maximum conductance, $n$ represents an activation gate, $E_{\mathrm{K}}$ is the potassium reversal potential, and $V$ is the membrane potential. $n$ follows the differential equation (Zagotta et al., 1994) $\frac{d n}{d t}=\alpha(1-n)-\beta n$ with the forward rate defined by $\alpha=C_{a} e^{z_{a} \frac{F V}{R T}}$ and the backward rate with $\beta=C_{b} e^{z_{b} \frac{F V}{R T}}$, where $C_{a}$ and $C_{b}$ are the rate constants at $0 \mathrm{mV}$, and $z_{a}$ and $z_{b}$ are the charge movements. $C_{a}, C_{b}, z_{a}$, and $z_{b}$ were obtained by fitting the steady-state curve, $F(V)=\frac{\alpha}{(\alpha+\beta)}$, and time constants, $\tau_{n}(V)=\frac{1}{(\alpha+\beta)}$, simultaneously and weighing with the SEs using the Global Fitting routine in Igor Pro. The fit was optimized with the following parameter values: $C_{a}=0.036 \mathrm{~ms}^{-1}, C_{b}=0.002 \mathrm{~ms}^{-1}, z_{a}=0.909$ $\mathrm{mV}$, and $z_{b}=1.102 \mathrm{mV}$ (see Fig. $9 A$ ). Calculations of conductance densities for outside-out and cell-attached patch-clamp recordings were based on published data of surface area measurements and were $4 \mu \mathrm{m}^{2}$ (Schmidt-Hieber and Bischofberger, 2010) and $2 \mu \mathrm{m}^{2}$ (Sakmann and Neher, 2009), respectively.

Compartmental modeling. Conductance-based multicompartmental simulations used the geometric morphology of an in vitro biocytin-filled thick-tufted L5 pyramidal neuron (cell number 30_08_12_1) threedimensionally reconstructed with Neurolucida (version 10, MicroBrightField Europe E.K. ) and imported into the NEURON simulation environment (version 7.3; Hines and Carnevale, 2001). Since nodes of Ranvier are only barely visible in bright-field microscopy, their approximate positions were also estimated by, for example, the branching of axon collaterals. The dimensions of the nodal compartments, six in total, were assigned nominally and progressively decreased in length (3.0-1.5 $\mu \mathrm{m})$ with distance from the soma. Throughout all compartments, the membrane resistance $\left(R_{\mathrm{m}}\right)$ was set to $25,000 \Omega \mathrm{cm}^{2}$, cytoplasmic resistance $\left(R_{\mathrm{i}}\right)$ to $140 \Omega \mathrm{cm}$, and membrane capacitance $\left(C_{\mathrm{m}}\right)$ to $1.2 \mu \mathrm{F} \mathrm{cm}^{-2}$. The resting membrane potential was set to $-78 \mathrm{mV}$. Myelination of internodal sections was represented by increasing internodal $R_{\mathrm{m}}$ fourfold and decreasing $C_{\mathrm{m}}$ sixfold, leading to a conduction velocity in the primary axons of $3.53 \mathrm{~m} \mathrm{~s}^{-1}$, in accordance with previous estimates (Kole et al., 2007). The axonal cut ending ("bleb") was connected to the last internode as a single unmyelinated compartment with a diameter of $5 \mu \mathrm{m}$.

$\mathrm{K}_{\mathrm{v}} 7$ peak conductance $\left(\bar{g}_{M}\right)$ was distributed based on the experimental findings (see Fig. 5), and was set to $15 \mathrm{pS} \mu \mathrm{m}^{-2}$ in all somatodendritic sections and increased linearly from 15 to $150 \mathrm{pS} \mu \mathrm{m}^{-2}$ from the middle to the end of the AIS. To estimate $\bar{g}_{\mathrm{M}}$ in nodal domains, we simulated whole-cell axonal $\mathrm{K}_{\mathrm{v}} 7$ currents activated during a single-electrode voltage-clamp simulation, using the point-process manager (SEClamp) of NEURON at the cut-end compartment. The $R_{\mathrm{s}}$ was set to $15.0 \mathrm{M} \Omega$ to match experimental conditions and simulations were run with time steps of $200 \mu \mathrm{s}$. Capacitive and leak currents were removed by subtracting the transients with current responses when $\bar{g}_{M}$ was set to zero. The axonal whole-cell current amplitudes (see Fig. $9 B$ ) will depend both on $\bar{g}_{M}$ as well as the electrode-to-node distance. To test the contribution of both parameters, we modeled the current amplitudes and varied the specific nodal $\bar{g}_{M}$ density $\left(1-300 \mathrm{pS} \mu \mathrm{m}^{-2}\right)$ and the distance of the cut-end to last node $(0.1-140 \mu \mathrm{m})$. Assuming that internodes are $\sim 150 \mu \mathrm{m}$ in length in the layer 6 region, the electrode-to-node distance will be on average $\sim 75$ $\mu \mathrm{m}$. At this distance, a nodal peak conductance density of $150 \mathrm{pS} \mu \mathrm{m}^{-2}$ led to a whole-axon peak amplitude of $475 \mathrm{pA}$ ( $28 \mathrm{mV}$ step), similar to the experimentally obtained average peak current ( $478 \pm 58 \mathrm{pA}, n=13)$. This computational estimate is in good agreement with the measured peripheral nodal $I_{\mathrm{K}}$ density of $18.8 \mathrm{nS} \mathrm{pF}^{-1}$ (Röper and Schwarz, 1989). In the model, $\bar{g}_{M}$ was therefore set to $150 \mathrm{pS} \mu \mathrm{m}^{-2}$ in nodes of Ranvier, $15 \mathrm{pS} \mu \mathrm{m}^{-2}$ in axon collaterals, and $1 \mathrm{pS} \mu \mathrm{m}^{-2}$ in the internodes.

$\mathrm{Na}_{\mathrm{v}}$ conductance was represented by two separate eight-state allosteric models developed for the soma and the axon (Schmidt-Hieber and Bischofberger, 2010) and distributed in density as described previously (Hallermann et al., 2012). In addition, the AIS sodium channel model was separately implemented by linearly shifting $\left(V_{\text {shift }}\right)$ the voltage dependence of inactivation of the axon model to account for the experimentally determined values from direct cell-attached recordings at the
AIS (Kole et al., 2008). The $V_{\text {half }}$ values of steady-state inactivation were $-55 \mathrm{mV}$ (soma), $-61 \mathrm{mV}$ (AIS), and $-75 \mathrm{mV}$ (axon). For steady-state activation, the $V_{\text {half }}$ values were $-22 \mathrm{mV}$ (soma), $-40 \mathrm{mV}$ (AIS), and $-44 \mathrm{mV}$ (axon). With these parameter values, most properties of single action potentials including amplitude, threshold, and rate of rise were well captured (see Fig. $10 A, D$ ). $\mathrm{K}^{+}$conductances were described by the following three $\mathrm{K}_{\mathrm{v}}$ channel models: a high-voltage threshold delayed type of non-inactivating model with properties similar to the $\mathrm{K}_{\mathrm{v}} 2$ channel (Mainen and Sejnowski, 1996); a recently developed axonal $\mathrm{K}_{\mathrm{v}} 1$ channel model (Hallermann et al., 2012), and the new $\mathrm{K}_{\mathrm{v}} 7$ model (see above). In addition, $\mathrm{Ca}^{2+}$-dependent $\mathrm{K}^{+}$channels, and low-voltage and highvoltage $\mathrm{Ca}^{2+}$ channels were assigned to the somatic and dendritic sections with densities as published previously (Mainen and Sejnowski, 1996; Hallermann et al., 2012). The HCN channel model was exponentially increasing in the apical dendrites (Kole et al., 2006) and with a low uniform density in axons $\left(1 \mathrm{pS} \mu \mathrm{m}^{-2}\right)$. The $\mathrm{K}^{+}$and $\mathrm{Na}^{+}$equilibrium potentials were set to -98 and $55 \mathrm{mV}$, respectively. The final input resistance of the model neuron was $22.4 \mathrm{M} \Omega$. Simulations were performed with a nominal temperature of $35^{\circ} \mathrm{C}$ and time steps between 5 and $10 \mu \mathrm{s}$.

Immunostaining. Two alternative strategies for immunostaining were developed, both relying on weak fixation, since even brief $4 \%$ paraformaldehyde (PFA) fixation abolished all $\mathrm{K}_{\mathrm{v}} 7$ AIS and nodal labeling (Pan et al., 2006). In one protocol (Fig. 1), 300- $\mu \mathrm{m}$-thick slices were immersion fixed (1\% PFA in $0.1 \mathrm{~m}$ PBS, $\mathrm{pH} 7.4$, for $30 \mathrm{~min}$ ), washed several times in $0.1 \mathrm{M} \mathrm{PBS}$, and stored at $4^{\circ} \mathrm{C}$ for up to 2 weeks before use in immunostaining. Before immunoreactions, antigen retrieval was performed by microwave irradiation in $10 \mathrm{~mm}$ citrate, $1 \mathrm{~mm}$ EDTA, and $0.05 \%$ Tween 20, pH 9.0, in mini-chambers (Shah et al., 2008). Slices were then washed in Tris-buffered saline (TBS), blocked (TBS, $2 \%$ Carnation non-fat dry milk, and $0.2 \%$ Triton X-100) for $1 \mathrm{~h}$ at room temperature, then incubated for $48 \mathrm{~h}$ in blocking buffer containing various combinations of the following primary antibodies: rabbit- $\alpha$-KCNQ2n; guinea pig- $\alpha$-KCNQ3n; mouse- $\alpha$-ankyrin G IgG2a; clone 106/36 [from the University of Calfornia, Davis/National Institutes of Health NeuroMab Facility, Davis, CA (UC Davis/Neuromab)]; mouse- $\alpha$-PanNa $\operatorname{IgG1}$ (Sigma-Aldrich); mouse- $\alpha$-NeuN IgG1 (Millipore Bioscience Research Reagents); and mouse $\alpha$-Caspr/paranodin/neurexin IV IgG1 (UC Davis/ Neuromab) at $4^{\circ} \mathrm{C}$. After extensive washes, the following slices were incubated in secondary antibodies overnight at $4^{\circ} \mathrm{C}$ : donkey- $\alpha$-rabbit DyLight 488 (Jackson ImmunoResearch); goat- $\alpha$-mouse Alexa Fluor 555 IgG2a $\gamma 2$ a (Life Technologies); goat- $\alpha$-mouse Alexa Fluor 647 IgG1 $\gamma 1$ (Life Technologies); and donkey- $\alpha$-guinea pig Cy5 (Jackson ImmunoResearch; Manning et al., 2012). After washing, slices were immersed in TBS containing DAPI (Life Technologies) for $20 \mathrm{~min}$ before mounting in Prolong Gold (Life Technologies) in imaging chambers made with plastic spacers (Grace Bio-Labs) and two coverslips (catalog \#474030, Zeiss).

An alternative protocol was used to detect $\mathrm{K}_{\mathrm{v}} 7.2$ and $\mathrm{K}_{\mathrm{v}} 7.3$ staining in electrophysiologically characterized cells (Fig. 2). L5 neurons were filled with Alexa Fluor 488 during whole-cell recordings. The $300-\mu \mathrm{m}$-thick slices were immersed in precooled methanol for $10 \mathrm{~min}$ at $-20^{\circ} \mathrm{C}$, washed with PBS, and blocked for $2-24 \mathrm{~h}$ at room temperature with PBS, $2 \%$ non-fat milk, and $0.2 \%$ Triton X-100. KCNQ2n and KCNQ3n primary antibodies were added, and the slices were incubated at room temperature overnight. Slices were then washed with PBS and incubated at room temperature with appropriate secondary antibodies conjugated with goat- $\alpha$-guinea pig Cy3 (Jackson ImmunoResearch) or goat- $\alpha$ rabbit Cy5 (Jackson ImmunoResearch) for $2 \mathrm{~h}$. Afterward, slices were washed in PBS and mounted in Prolong Gold with DAPI.

Confocal imaging and analysis. The L5 hindlimb somatosensory cortex region was identified according to atlas coordinates (Paxinos and Watson, 2007). Images were acquired using a Nikon C2 laser scanning confocal microscope, NIS-Elements 4.0 software, and either $2 \times 0.1$ numerical aperture (NA) Planapo or $60 \times 1.40$ NA Planapo VC objectives (Nikon Instruments). For quantification experiments, highresolution image stacks ( $z$-interval, $0.25 \mu \mathrm{m}$; pinhole, 1.0 Airy unit), acquired within the range $10-70 \mu \mathrm{m}$ below the slice surface, were used for analysis. Only cells whose somata, AISs, and proximal dendrites were entirely contained within the imaged volume were included in subse- 


\section{A}
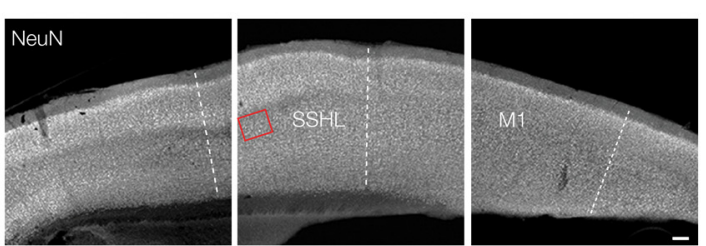

C
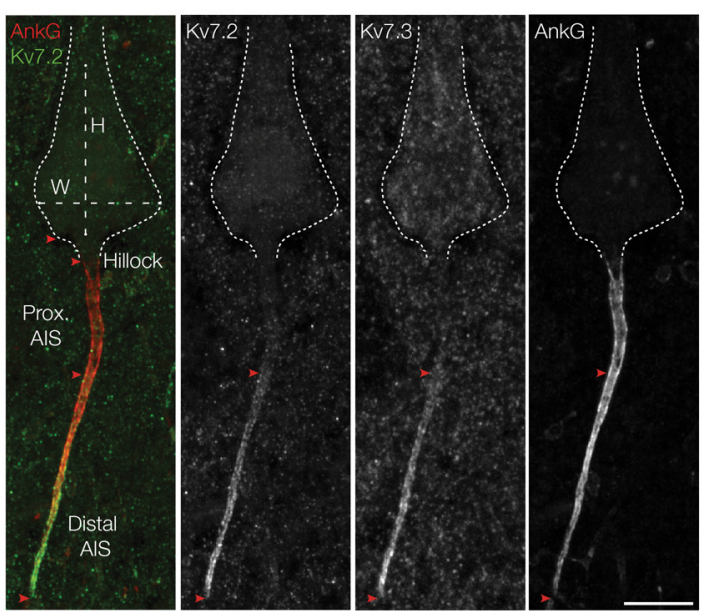

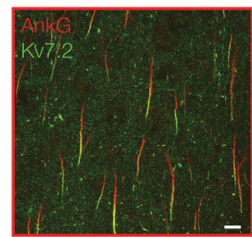

D
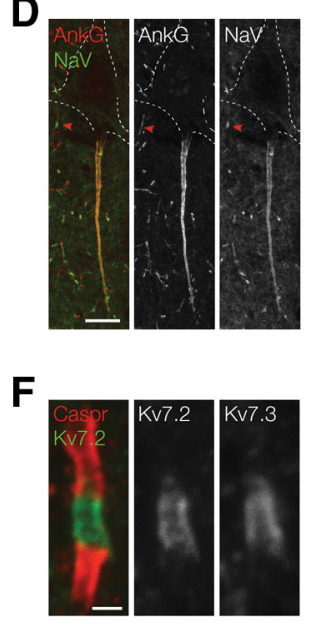

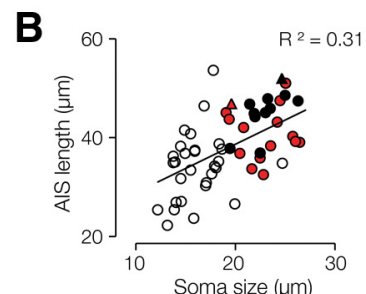

$E$
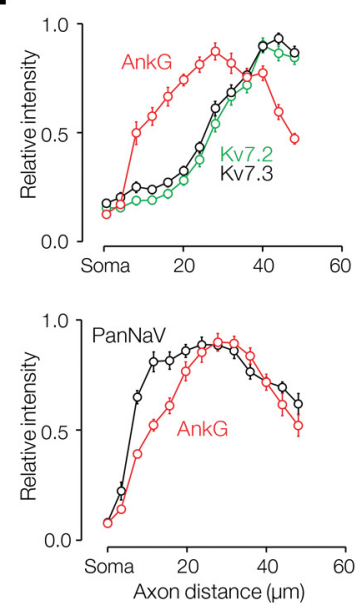

Figure 1. $\quad \mathrm{K}_{\mathrm{v}} 7$ and $\mathrm{Na}_{\mathrm{v}}$ channels are expressed in nonidentical gradients along neocortical pyramidal neuron AISs and colocalize at nodes of Ranvier. A, Left, At low magnification, NeuN labeling reveals the laminar neocortical structure in a parasagittal brain slice. Somatosensory hindlimb (SSHL) and primary motor (M1) areas are indicated. Scale bar, $100 \mu$ m. Right, The L5 somatosensory region (red box, left) is shown at higher magnification, immunolabeled for ankyrin $\mathrm{G}$ (AnkG; red) and $\mathrm{K}_{\mathrm{v}} 7.2$ (green). Scale bar, $10 \mu \mathrm{m}$. B. AIS length is positively correlated with soma size [(height + width)/2]. Least-squares fit shows a positive correlation $\left(R^{2}=0.31\right.$; fit equation: $L_{\text {AIS }}=0.98$ (somasize) +19.082 ). Red triangle, neuron shown in $C$; black triangle, neuron shown in $\boldsymbol{D}$; red circles, set of larger neurons used to plot $K_{\mathrm{v}} 7.2$ and $K_{\mathrm{v}} 7.3$ labeling intensity vs axon distance (shown in $\boldsymbol{E}$, top); closed circles, larger neurons used to plot PanNa $\mathrm{V}_{\mathrm{v}}$ labeling intensity vs axon distance $(\boldsymbol{E}$, bottom); open circles, smaller neurons that were not included in length measurements. C, Maximal projection image of a large $L 5$ somatosensory neuron, colabeled for $\mathrm{K}_{\mathrm{v}} 7.2, \mathrm{~K}_{\mathrm{v}} 7.3$, and ankyrin $\mathrm{G}$. The somatic height $(\mathrm{H})$ and width $(\mathrm{W})$, origin and end of the hillock, proximal AIS, and distal AIS are indicated. Both $\mathrm{K}_{\mathrm{v}} 7$ channel subunits are restricted to the distal AIS, wherein intensity increases in a gradient toward the tip. Scale bar, $10 \mu \mathrm{m}$. D, Maximal projection image of a large $\mathrm{L} 5$ somatosensory neuron, colabeled for ankyrin $\mathrm{G}$ and PanNa. The AlS pattern of $\mathrm{PanNa}_{\mathrm{v}}$ (detecting all neuronal $\mathrm{Na}_{\mathrm{v}}$ channel isoforms) and ankyrin $\mathrm{G}$ appear similar. Arrowheads indicate one of many nodes of Ranvier visible in the image ( $\mathrm{PanNa}_{\mathrm{v}}$ labeling the unmyelinated node, ankyrin G labeling the node and flanking paranodes). Scale bar, $10 \mu \mathrm{m}$. E, Plots of AIS relative labeling intensity vs distance from the axonal origin. Top, $\mathrm{K}_{\mathrm{v}} 7.2$ and $\mathrm{K}_{\mathrm{v}} 7.3$ labeling profiles are similar: low in the proximal one-third and increasing progressively toward the distal AIS tip $(n=15)$. Bottom, Ankyrin $\mathrm{G}$ and PanNa $\mathrm{V}_{\mathrm{v}}$ label the entire AIS, with a broad intensity peak near the midpoint $(n=10)$. Points show the mean \pm SEM of pixel intensity in fractional distance bins along the AIS. $F$, High-magnification image of a larger node of Ranvier within the $L 5$ somatosensory cortex. $K_{v} 7.2$ and $K_{v} 7.3$ colabel the nodal membrane flanked by Caspr at the paranodes. Scale bar, $1 \mu \mathrm{m}$.

quent measurements of somatic and AIS size and labeling. Pyramidal cell soma size was estimated as [height $(\mathrm{H})+$ width $(\mathrm{W})] / 2$ (Sloper and Powell, 1979). The mean labeling intensity in the neuropil for ankyrin G, $\mathrm{PanNa}_{\mathrm{v}}, \mathrm{K}_{\mathrm{v}} 7.2$, and $\mathrm{K}_{\mathrm{v}} 7.3$ was low. Although several methods of setting black levels gave equivalent results, for the calculations shown we measured the mean neuropil intensity (manually adjusted to exclude AISs, somata, and proximal dendrites in each image) for each antibody for each image stack, and subtracted this value from all images. The 3D trajectory and labeling intensity of each proximal axon was measured as follows: using maximal projection and $3 \mathrm{D}$ views in NIS-Elements, we drew a 3D polyline along the axon, from within the soma to beyond the AIS. This was converted to a $2 \mathrm{D}$ ( $x$ and $y$ vs $z$ ) plot using the "kymograph" tool, and labeling at each pixel along the trajectory for each fluorophore was read using the "intensity profile" tool and exported to Excel (Microsoft). To average the raw intensity profiles of axons varying in AIS length, we first determined the individual and average lengths of the axon hillocks (i.e., the proximal origin of the axon from the soma or a dendrite, lacking strong $\mathrm{Na}_{\mathrm{v}}$ and ankyrin G labeling) and AISs. Pixel intensity data from individual axon profiles were binned, and values normalized to the maximum intensity bin for that axon and fluorophore. Normalized intensities of bins representing equivalent fractional distances along the AISs were then averaged $( \pm$ SEM $)$. To determine the percentage of nodes of Ranvier bearing $\mathrm{K}_{\mathrm{v}} 7.2$ and $\mathrm{K}_{\mathrm{v}} 7.3$, counts were made in stacks from L5 hindlimb somatosensory cortex region sections colabeled either for ankyrin $\mathrm{G}$ or Caspr.

For the Alexa Fluor-filled L5 pyramidal neurons, $z$-stacks with a step size of $0.25-1 \mu \mathrm{m}$ were acquired sequentially for each fluorophore using a Leica SP5 confocal microscope, a $63 \times 1.4$ NA Leica Planapo objective, and supplier-provided software (Leica Microsystems). Maximal projection images were adjusted for brightness and contrast in FIJI (ImageJ, version 1.47a). A background value (the mean intensity within a circular region of interest lacking AISs or somata) was subtracted from each channel.

\section{Results}

$K_{v} 7.2$ and $K_{v} 7.3$ subunits colocalize with $\mathrm{Na}_{v}$ channels at neocortical AISs and nodes of Ranvier

To enable correlation of $\mathrm{K}_{\mathrm{v}} 7$ channel protein subcellular distribution and function, we en bloc immunostained 300- $\mu$ m-thick parasagittal brain slices containing primary somatosensory and motor cortex (Fig. 1A, left) using well characterized specific antibodies against $\mathrm{K}_{\mathrm{v}} 7.2, \mathrm{~K}_{\mathrm{v}} 7.3$, and $\mathrm{Na}_{\mathrm{v}}$ channel principal subunits $\left(\mathrm{PanNa}_{\mathrm{v}}\right)$, along with markers of neuronal somata $(\mathrm{NeuN})$, initial segments (ankyrin G), and nodes of Ranvier (Caspr/paranodin/ neuroexin IV). Single-photon scanning confocal microscopy revealed a strong staining signal to a depth of at least $\sim 70 \mu \mathrm{m}$, allowing the collection of image sets containing complete views of neuronal proximal dendrites, somata, and AISs. Pyramidal cell AISs of layer 5 showed a stereotyped channel distribution: ankyrin G strongly labeled the entire AIS, whereas strong labeling for $\mathrm{K}_{\mathrm{v}} 7.2$ was restricted to the distal part of the AIS (Fig. 1A, right).

In L5 of the somatosensory cortex, we measured pyramidal cell soma size $(19.3 \pm 0.6 \mu \mathrm{m})$, hillock length $(3.5 \pm 0.9 \mu \mathrm{m})$, and AIS length (43.68 $\pm 4.69 \mu \mathrm{m}$; all $n=55)$, and quantified the 

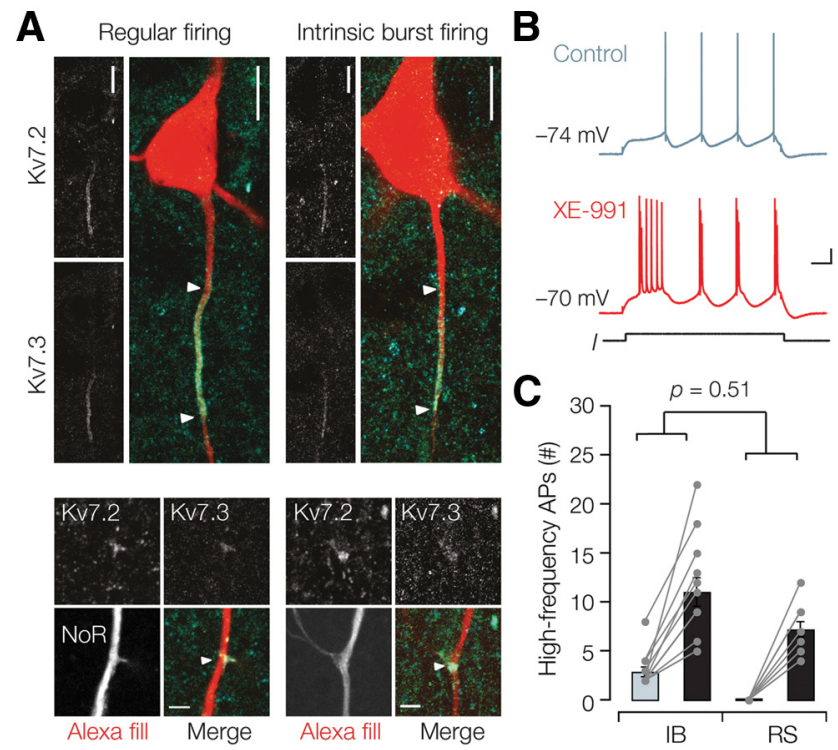

Figure 2. $K_{v} 7.2$ and $K_{v} 7.3$ colocalize at AISs and nodes of Ranvier of functionally identified L5 pyramidal neurons. $\boldsymbol{A}$, Top, z-projected confocal images of the soma and AIS morphology (red, Alexa Fluor 488 fill) and immunofluorescence staining of $K_{v} 7.2$ (cyan) and $K_{v} 7.3$ (green) in RS and $I B$ neurons. White arrows indicate the region of the $K_{v} 7$ immunostaining. Images are background subtracted and pseudo-colored. Scale bars, $10 \mu \mathrm{m}$. Bottom, Nodes of Ranvier (NoR) indicated by axonal bifurcation points of identified RS and IB neurons. White arrows indicate positive staining for $\mathrm{K}_{\mathrm{v}} 7.2 / 7.3$ at the NoR. Scale bars, $3 \mu \mathrm{m}$. $\boldsymbol{B}$, Example of a regular firing neuron that was converted into intrinsic burst firing during bath application of XE-991 (red). Calibration: $0.1 \mathrm{~s}, 20 \mathrm{mV}$. C, Scatter and bar plots of RS and IB groups show a similar increase in high-frequency action potentials after application of $20 \mu \mathrm{M}$ XE-991. Scatter plot, Individual experiments. Bars represent mean \pm SEM.

channel staining intensity profiles along the AIS. In contrast to earlier electron microscope studies based on a smaller number of cells (Sloper and Powell, 1979), we detected a positive correlation between AIS length and soma size (Pearson's, test $p=0.01$, Fig. $1 B$ ). Although $\mathrm{K}_{\mathrm{v}} 7.2, \mathrm{~K}_{\mathrm{v}} 7.3$, ankyrin $\mathrm{G}$, and $\mathrm{PanNa}_{\mathrm{v}}$ staining were concentrated within the AIS, high-resolution imaging showed that the two $\mathrm{K}_{\mathrm{v}} 7$ subunits were strictly colocalized within the distal portion of each AIS, whereas $\mathrm{Na}_{\mathrm{v}}$ staining filled the entire AIS, indicating that the subcellular $\mathrm{Na}_{\mathrm{v}}$ and $\mathrm{K}_{\mathrm{v}} 7$ profiles are distinct. Semiquantitative image analysis showed that staining for $\mathrm{K}_{\mathrm{v}}$ 7.2/7.3 followed similar profiles, scaled with AIS length, and was confined to the distal fraction of the length of ankyrin $G$ labeling $\left(0.7 \pm 0.1, n=10\right.$, for both $\mathrm{K}_{\mathrm{v}} 7.2$ and $\left.\mathrm{K}_{\mathrm{v}} 7.3\right) . \mathrm{K}_{\mathrm{v}} 7.2 / 7.3$ staining peaked at the distal tip and was thus distinct from the subcellular ankyrin $\mathrm{G}$ distribution (Fig. $1 C-E$ ). The relative $\mathrm{Na}_{\mathrm{v}}$ intensity, however, peaked broadly near the AIS midpoint and then declined, a pattern that strongly paralleled the ankyrin $G$ distribution (Fig. 1D,E). Nodes of Ranvier were abundant in all layers of the neocortical gray matter and appeared strongly labeled by $\mathrm{PanNa}_{\mathrm{v}}$ (Fig. 1D, arrowhead) or $\mathrm{K}_{\mathrm{v}} 7.2 / 7.3$ flanked by Caspr antibodies (Fig. $1 F$ ). In L5, we counted 265 nodes, of which $259(98 \%)$ were labeled by $\mathrm{K}_{\mathrm{v}} 7.2$ and 256 (97\%) were labeled by $\mathrm{K}_{\mathrm{v}} 7.3$, which is indicative of the expression of both subunits in nearly all nodes. Nodes of Ranvier, as estimated from highmagnification images (Fig. $1 F$ ), were $0.97 \pm 0.02 \mu \mathrm{m}$ long and $0.66 \pm 0.01 \mu \mathrm{m}$ in diameter $(n=259)$. In some nodes, especially those well aligned with the $x-y$ plane, the staining for $\mathrm{K}_{\mathrm{v}} 7.2 / 7.3$ (Fig. $1 F$ ) and $\mathrm{PanNa}_{\mathrm{v}}$ appeared in parallel lines, suggestive of membrane labeling. These findings show that while $\mathrm{K}_{\mathrm{v}} 7$ and $\mathrm{Na}_{\mathrm{v}}$ are coexpressed in neocortical AISs and nodes, they follow distinct distributions within the AIS with highest absolute and rela- tive $\mathrm{K}_{\mathrm{v}} 7.2 / 7.3$ concentrations at the distal AIS $(\sim 40 \mu \mathrm{m})$ coinciding with the site of action potential onset (Palmer and Stuart, 2006; Kole et al., 2007).

\section{Intrinsically bursting and regular firing L5 neurons have similar axonal $\mathrm{K}_{\mathrm{v}} 7$ distributions}

For our subsequent electrophysiological characterization experiments, we investigated the $\mathrm{K}_{\mathrm{v}} 7$ distribution in identified L5 neurons that can be classified by their regular spiking (RS) and intrinsic bursting (IB) phenotypes (Chagnac-Amitai et al., 1990; Kole, 2011). We recorded from large thick-tufted L5 neurons, filled these with Alexa Fluor 488, and performed post hoc $\mathrm{K}_{\mathrm{v}} 7.2$ and $\mathrm{K}_{\mathrm{v}} 7.3$ staining. $z$-projected image analysis revealed that neither the soma size (on average, $22.1 \pm 0.5 \mu \mathrm{m}$; unpaired $t$ test, $p=0.47$ ) nor the AIS length (on average, $45.7 \pm 1.1 \mu \mathrm{m} ; p=$ 0.10 ) was different between the two classes (17 RS and 12 IB neurons). Furthermore, the length of expression in the distal part of the AIS was similar between the two classes for both $\mathrm{K}_{\mathrm{v}} 7.2$ (RS, $23.7 \pm 1.3 \mu \mathrm{m}, n=14$; IB, $24.9 \pm 1.6 \mu \mathrm{m}, n=9$; unpaired $t$ test, $p=0.57$; Fig. $2 A$ ) and $\mathrm{K}_{\mathrm{v}} 7.3$ (RS, $24.6 \pm 1.3 \mu \mathrm{m}, n=12$; IB, $25.8 \pm 1.7 \mu \mathrm{m}, n=9 ; p=0.59$; Fig. $2 A) . \mathrm{K}_{\mathrm{v}} 7.2$ and 7.3 subunits were also coexpressed at all identified axonal branch points (100\%, 11 branch points) in both RS (five of five branch points) and IB neurons (six of six branch points; Fig. 2A).

To determine the physiological contribution of the total $\mathrm{K}_{\mathrm{v}} 7$ conductance to the intrinsic excitability in the two classes, we analyzed the change in intrinsic excitability after bath application (10-20 $\mu \mathrm{M}$ ) of XE-991, a $\mathrm{K}_{\mathrm{v}} 7$ family-selective blocker (Wang et al., 1998). The results indicate that IB and RS neurons similarly increased in input resistance $(124 \pm 8.6 \%$ and $115.7 \pm 8.6 \%$, respectively; two-way repeated-measures ANOVA, $p=0.44, n=$ $6)$ and depolarized their resting membrane potential $(+3.8 \pm 0.8$ vs $+4.3 \pm 1.2 \mathrm{mV}$, IB and RS, respectively; $p=0.60$ ). Furthermore, the percentage increase in the action potential afterdepolarization (ADP) after bath application of $20 \mu \mathrm{M}$ XE-991 was not different $(244.7 \pm 48 \%$ vs $182.4 \pm 17.7 \%$, for IB and RS, respectively; $p=0.28 ; n=6$ ), and neither the change in the number of high-frequency action potentials $(8.1 \pm 1.3$ vs $7.2 \pm 1.0, \mathrm{IB}$ and RS, respectively; $p=0.54 ; n=13$ and $n=11$; Fig. $2 B, C)$.

Together, these results strongly indicate that $K_{v} 7.2$ and $K_{v} 7.3$ subunits are, independent of pyramidal cell subtype, strictly colocalized to the distal region of the AIS and ubiquitously clustered near $\mathrm{Na}_{\mathrm{v}}$ channels. Although strict colocalization of the two $\mathrm{K}_{\mathrm{v}} 7$ subunits at both AISs and nodes is suggestive of the expression of heterotetrameric channels, as noted earlier (Pan et al., 2006), this can only be established by direct M-current recording from the axon.

\section{Pharmacological isolation and identification of $I_{M}$ in neocortical axons}

To record axonal $I_{\mathrm{M}}$, we made whole-cell recordings from the unmyelinated cut-ends of visually identified L5 axons (Kole et al., 2007). Using a $-92 \mathrm{mV}$ holding potential, a step depolarization in the axon to $8 \mathrm{mV}$ activated a rapid inward $\mathrm{Na}^{+}$current followed by a slowly inactivating $\mathrm{K}^{+}$outward current (Fig. 3A). We pharmacologically isolated $I_{M}$ by bath application of TTX, 4-AP, and ZD-7288, blocking $\mathrm{Na}^{+}$currents, fast-activating $\mathrm{K}_{\mathrm{v}} 1$ and $\mathrm{K}_{\mathrm{v}} 3$-type $\mathrm{K}^{+}$currents, and $\mathrm{HCN}$ currents, respectively. The remaining outward current was relatively slowly rising $(28.8 \pm 5.1$ $\mathrm{ms}$ at $8 \mathrm{mV} ; n=5$ axons) and non-inactivating, suggestive of $I_{\mathrm{M}}$ (Fig. 3A, black trace; Brown and Adams, 1980; Brown and Passmore, 2009). The space-clamp characteristic of this voltageclamp configuration was assessed by placing a second electrode at 
the soma while injecting the voltage command steps into the axon $(n=5$ somaaxon recordings, $120-650 \mu \mathrm{m}$ from the soma and $n=2$ soma-soma recordings; Fig. $3 B, C)$. Voltage command amplitudes greatly attenuated with increasing distances from the axonal injection site, following a single exponential function with a constant of $149 \mu \mathrm{m}(n=7$; Fig. $3 C)$. These results indicate that axonal recordings beyond $300 \mu \mathrm{m}$ distance from the soma and injecting, for example, a step potential of $100 \mathrm{mV}$ will depolarize the soma by less than $\sim 15 \mathrm{mV}$, minimally activating somatodendritic $\mathrm{K}^{+}$currents. All axonal whole-cell voltage-clamp recordings were therefore routinely made at a distance of $\sim 400-800 \mu \mathrm{m}$ from the soma.

To pharmacologically characterize the axonal $I_{\mathrm{M}}$, we first bath applied XE-991. Outward currents were dose-dependently blocked to $63.3 \pm 7.6 \%(n=6)$ at $10 \mu \mathrm{M}$ and maximally to $76.7 \pm 1.6 \%(n=5)$ at $100 \mu \mathrm{M}$ (Fig. $3 D$ ). The $\mathrm{IC}_{50}$ of XE-991 determined with the Hill equation was 1.9 $\mu \mathrm{M}$ with a Hill slope near unity $(\sim 0.95)$, which is similar to previous reports (Wang et al., 2000; Schwarz et al., 2006).

Since all $\mathrm{K}_{\mathrm{v}} 7$ family members are similarly sensitive to XE-991, these results indicated that the current was largely mediated by $\mathrm{K}_{\mathrm{v}} 7$ channels, but did not allow identification of the subunits. To achieve this, we exploited the differential sensitivity of homomeric and heteromeric $\mathrm{K}_{\mathrm{v}} 7$ channels to the $\mathrm{K}^{+}$channel blocker TEA (Wang et al., 1998; Hadley et al., 2000, 2003; Schroeder et al., 2000; Shapiro et al., 2000). Homomeric $\mathrm{K}_{\mathrm{v}} 7.2, \mathrm{~K}_{\mathrm{v}} 7.3, \mathrm{~K}_{\mathrm{v}} 7.4$, and $\mathrm{K}_{\mathrm{v}} 7.5$ channels are blocked with $\mathrm{IC}_{50}$ values of $\sim 0.17,>200$, $\sim 3.0$, and $\sim 70 \mathrm{mM}$, respectively. Importantly, $\mathrm{K}_{\mathrm{v}} 7.4$ subunits have a restricted expression pattern in brain and have not been found in neocortex (Kharkovets et al., 2000). Heteromeric channels show intermediate sensitivities to TEA block. $\mathrm{K}_{\mathrm{v}} 7.2 / 7.3$ and $\mathrm{K}_{\mathrm{v}} 7.2 / 7.5$ channels have $\mathrm{IC}_{50}$ values near $\sim 3$ and $\sim 200 \mathrm{mM}$ (Wang et al., 1998; Hadley et al., 2000, 2003; Schroeder et al., 2000; Shapiro et al., 2000). We found that bath application of 3 mM TEA blocked $42.3 \pm 6.4 \%(n=3)$ of the 4-AP-insensitive outward currents; $30 \mathrm{mM}$ TEA blocked 78.1 $\pm 6.8 \%(n=5$, paired $t$ test $p=0.00058$; Fig. $3 E$ ). Fitting TEA inhibition results at concentrations of $0.1,0.3,3.0$, or $30 \mathrm{~mm}$ yielded $\mathrm{an} \mathrm{IC}_{50}$ of 2.9 $\mathrm{mm}$ with a Hill slope coefficient of 1.2. Together, in L5 axons the remaining outward current in the presence of 4-AP resembles the XE991-sensitive $I_{\mathrm{M}}$, predominantly carried by heterotetramers of $\mathrm{K}_{\mathrm{v}} 7.2 / 7.3$ subunits.

\section{Gating properties, voltage dependence, and retigabine sensitivity of axonal $\mathrm{K}_{\mathrm{v}} 7.2 / 7.3$ channels}

To examine the precise voltage dependence and kinetics of axonal heterotetrameric $\mathrm{K}_{\mathrm{v}}$ 7.2/7.3 channels, we used a deactivation protocol from a holding potential of $-32 \mathrm{mV}$ (Brown and Adams, 1980; Adams et al., 1982). Between -32 and $-62 \mathrm{mV}$, the inwardly rectifying currents deactivated slowly ( $\sim 30$ to $40 \mathrm{~ms})$ and inverted beyond voltages of $-100 \mathrm{mV}$ (Fig. 4A). Analysis of the intersection of the instantaneous and steady-state currents obtained with the deactivation protocol yielded a reversal potential
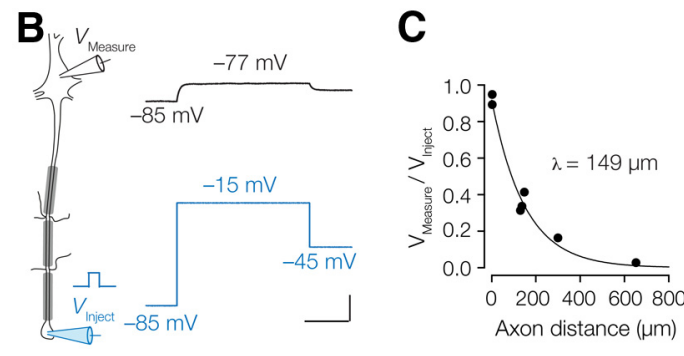

\section{E}
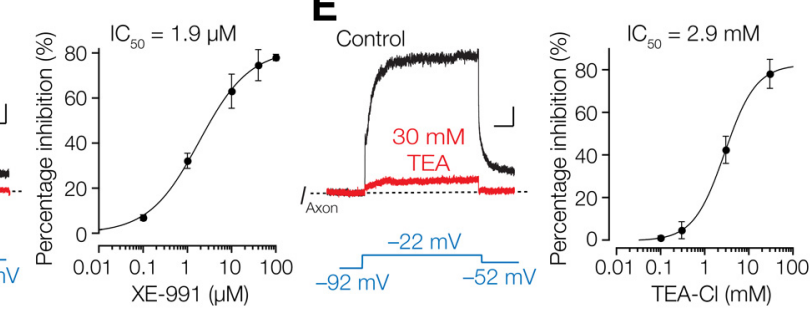

TEA-Cl (mM)

Figure 3. Isolation and pharmacological characterization of $I_{M}$ in neocortical axons. $A$, Left, Pipette configuration during single electrode whole-axon voltage-clamp recording. Right, Voltage steps to $8 \mathrm{mV}$ evoked a $\mathrm{Na}^{+}{ }^{+}$-mediated fast inward current fol20 me distance from the soma and fitted with the exponential function; $y=$ , $\boldsymbol{E}_{\mathrm{v}} 7$ channel blocker XE-991 (D) and the nonspecific blocker TEA $(\boldsymbol{E})$ blocked the outward currents. and TEA $(n=12)$, respectively. Symbols represent the mean \pm SEM.

of on average $-92.6 \pm 4.3 \mathrm{mV}(n=7)$, which is consistent with a $\mathrm{K}^{+}$current. We also explored the voltage and time dependence of $I_{\mathrm{M}}$ activation by making steps from a holding potential of -92 $\mathrm{mV}$ to a range of test potentials ( -102 to $32 \mathrm{mV}$ ), followed by a step to $-52 \mathrm{mV}$ (Fig. $4 B$ ). Outward currents were clearly resolved from -62 , and at $28 \mathrm{mV}$ reached peak amplitudes of on average $478.7 \pm 58.1 \mathrm{pA}$, equivalent to a conductance of $4.0 \pm 0.5 \mathrm{nS}$ (assuming a $-92 \mathrm{mV}$ reversal potential; $n=14$; Fig. $4 B, C$ ). Bath application of the $\mathrm{K}_{\mathrm{v}} 7.2-7.5$ channel opener retigabine (Wickenden et al., 2000) at a concentration of $10 \mu \mathrm{M}$ led to a nearly twofold increase in peak conductance $(7.5 \pm 0.22 \mathrm{nS}, p=$ $0.00012, n=4$; Fig. $4 A-C$ ).

Tail currents were analyzed for both the activation and deactivation protocols. We found that the midpoints of voltage dependence of activation and effective valances, determined by Boltzmann fits, were not different between the two protocols ( $p=0.328$ and $p=0.531$, respectively) and therefore subsequently pooled the results. The average midpoint for voltage dependence of activation was $-33.8 \pm 1.8 \mathrm{mV}(n=8)$ with an effective valence $\left(e^{-}\right)$of $3.1 \pm 0.3(n=8$; Fig. $4 D)$. Retigabine strongly shifted the midpoint of the voltage dependence of activation to $-63.1 \pm 1.6 \mathrm{mV}$ (unpaired $t$ test, $p=0.00023 ; n=6$; Fig. $4 D$ ), which is in line with the predicted shift of approximately $-30 \mathrm{mV}$ for $\mathrm{K}_{\mathrm{v}}$ 7.2/7.3 heteromers (Tatulian et al., 2001). The time course of activation and deactivation could be well fitted with single exponential functions revealing relatively fast kinetics ranging between 10 and $40 \mathrm{~ms}$ at $35^{\circ} \mathrm{C}$ (Fig. $4 E$ ). Bath application of $10 \mu \mathrm{M}$ retigabine led to a fivefold slowing of the deactivation time constant (at $-72 \mathrm{mV}$; control, $18.9 \pm 1.9 \mathrm{~ms}, n=10$; retigabine $89.6 \pm 10.9 \mathrm{~ms}, n=4$; unpaired $t$ test, $p=0.0013$; Fig. $4 E$ ) but did not affect activation at depolarized potentials $(8 \mathrm{mV}$; control, $21.7 \pm 0.3 \mathrm{~ms}, n=10$; retigabine, $25.8 \pm 1.7 \mathrm{~ms}, n=4$; $p=0.268$; Fig. $4 E$ ). The slowing of the $I_{\mathrm{M}}$ deactivation of retigabine in L5 pyramidal cell axons is consistent with previous exper- 
A
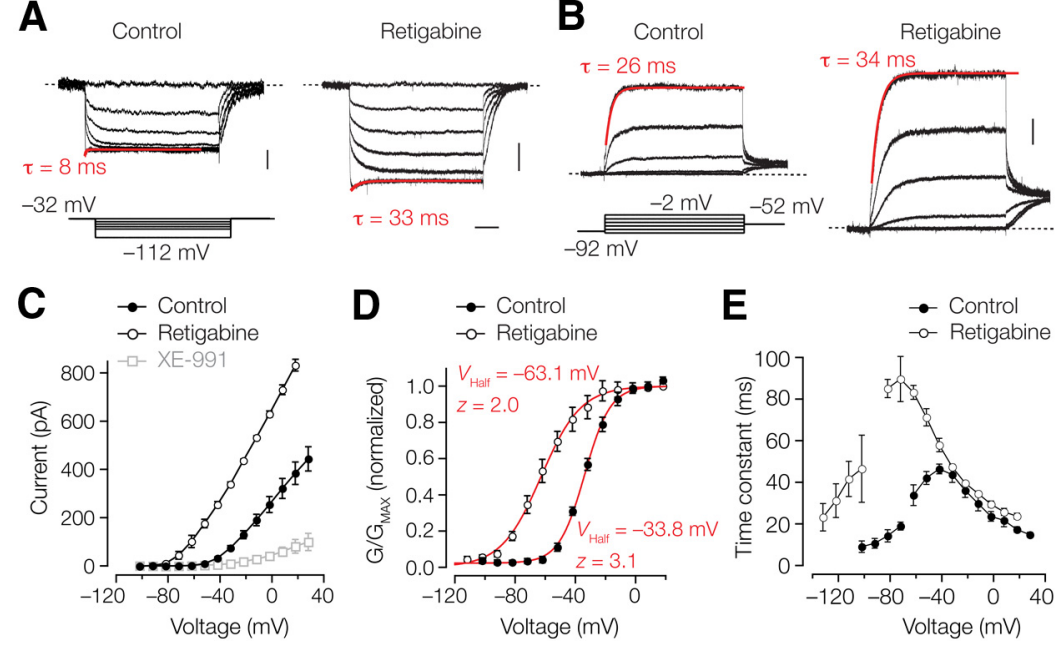

Figure 4. Voltage dependence, kinetics, and retigabine sensitivity of nodal M-currents. $\boldsymbol{A}$, Deactivation currents under contro conditions (left) and in the presence of retigabine (right). Traces represent average of five different axons. Calibration: 20 and 100 $\mathrm{pA}, 0.1 \mathrm{~s} . \boldsymbol{B}, I_{\mathrm{M}}$ activation in response to six voltage steps (left). Current traces (average of three axons) of $I_{\mathrm{M}}$ to the same voltage steps recorded in the presence of $10 \mu \mathrm{m}$ retigabine (right). Calibration: $0.1 \mathrm{nA}$; same time scale applies as in $\boldsymbol{A}$. Single exponential fits (red) of the current rise time are overlaid only for the maximal activated current. C, Current-voltage plots of the peak current amplitude obtained during activation in control, retigabine, and XE-991. D, Normalized conductance-voltage plots fitted with Boltzmann equations with offset for control and in the presence of retigabine. The half-maximum activation and effective valences are indicated. $\boldsymbol{E}$, Time constants of activation and deactivation obtained from monoexponential fits are shown. $I_{M}$ was significantly slower between -132 and $-42 \mathrm{mV}$ in the presence of retigabine. All symbols represent the mean $\pm \mathrm{SEM}$.

course of activation was on average $13.4 \pm$ $3.5 \mathrm{~ms}(n=7)$. Second, using deactivation steps to $-52 \mathrm{mV}$ revealed slower current relaxations $(2-8 \mathrm{pA}$ in amplitude) that could be well fitted with a single exponential with a time constant of $43.6 \pm 4.6 \mathrm{~ms}(n=5)$. The observed $\mathrm{M}$-current kinetics in the AIS therefore resembled the whole-axon currents (Fig. 4). To rule out any voltage-clamp errors in cell-attached mode (Williams and Wozny, 2011), we also made outside-out patchclamp recordings from the distal AIS in the presence of 4-AP, ZD-7288, and TTX, and applied deactivation steps. M-currents could successfully be detected in four outside-out recordings and were slowly deactivating at $-32 \mathrm{mV}(40.7 \pm 6.7 \mathrm{~ms} ; n=4$; Fig. $5 A, B)$, which is comparable to the whole-axon kinetics (unpaired $t$ test, $p=$ $0.639)$. The average half-maximum activation voltage from three separate fits was $-38.4 \pm 0.1 \mathrm{mV}$ with an effective valence of $2.5 \pm 0.1(n=3)$.

The patch recordings allowed us to quantify the density of $I_{\mathrm{M}}$ along the somatodendritic and axonal axis by converting the obtained peak current amplitudes to

iments using heterologously expressed $\mathrm{K}_{\mathrm{v}}$ 7.2/7.3 heteromers (Tatulian et al., 2001). To enable comparison with previous $\mathrm{K}_{\mathrm{v}} 7$ studies performed at room temperature, we also recorded $I_{\mathrm{M}}$ at a temperature of $25^{\circ} \mathrm{C}$. At $32 \mathrm{mV}$, the activation time constant became significantly slower from an average of $14.8 \pm 2.2 \mathrm{~ms}$ $\left(35^{\circ} \mathrm{C} ; n=9\right)$ to $61.7 \pm 6.4 \mathrm{~ms}\left(25^{\circ} \mathrm{C} ; n=5\right.$; unpaired $t$ test, $p=$ $0.0086)$, and at $-50 \mathrm{mV}$ changed from $42.1 \pm 4.8 \mathrm{~ms}(n=9)$ to $114.9 \pm 15.1 \mathrm{~ms}(n=5 ; p=0.0074)$. Across a range of voltage steps, the temperature coefficient $\left(\mathrm{Q}_{10}\right)$ was found to be on average $\sim 2.6$, which is in accord with previous work in layer $2 / 3$ neurons (Guan et al., 2011).

In summary, these data show that axonal $I_{\mathrm{M}}$ shares the voltage dependence with previously reported somatic $I_{\mathrm{M}}$, but has relatively faster and monoexponential activation and deactivation kinetics.

\section{$I_{\mathrm{M}}$ properties in the axon initial segment}

Whole-axon recordings most likely recruit ionic current from nodes of Ranvier located at various distances from the recording location, possibly leading to a filtering of the current rise times. Since the AIS contains high densities of $\mathrm{K}_{\mathrm{v}} 7.2 / 7.3$ channels (Figs. 1,2 ) and is amenable to direct patch-clamp recording (Kole et al., 2007), we made cell-attached recordings using large depolarizing steps to $45 \mathrm{mV}$, maximizing the probability to detect small currents. Outward currents evoked in somatic cell-attached patches were $<2 \mathrm{pA}(n=8)$, and in some cases single-channel openings were resolved (Fig. 5A, top traces). Single-channel currents were on average $1.6 \pm 0.06 \mathrm{pA}$ (single-channel conductance; $10.7 \pm$ $0.7 \mathrm{pS} ; n=4$ patches), which is consistent with previously reported single $\mathrm{M}$-channel conductances ranging between 7 and 11 pS (Selyanko et al., 2001; Chen and Johnston, 2004; Miceli et al., 2009). In contrast to the soma, significantly larger and macroscopic currents were obtained at a distance of $\geq 30 \mu \mathrm{m}$ from the soma in the AIS (range, $5-38 \mathrm{pA} ; n=8 ; p=0.0032$; Fig. $5 A$ ). AIS cell-attached currents strongly resembled $I_{\mathrm{M}}$. First, the time conductance densities, using the experimentally determined reversal potential of $-92 \mathrm{mV}$. On average, the densities in somatic and dendritic patches were determined to be $12.1 \pm 0.3 \mathrm{pS} \mu \mathrm{m}^{-2}$ $(n=22)$ and $12.2 \pm 2.4 \mathrm{pS} \mu \mathrm{m}^{-2}(n=5)$, respectively (Fig. $\left.5 C\right)$, which is equivalent to $\sim 1-2 \mathrm{~K}_{\mathrm{v}} 7$ channels $/ \mu \mathrm{m}^{2}$, assuming a single-channel conductance of 7-11 pS (Selyanko et al., 2001; Chen and Johnston, 2004; Miceli et al., 2009). The collected data demonstrated, however, a steep increase in current amplitudes beyond $30 \mu \mathrm{m}$ from the soma, reaching a peak conductance density of $\sim 144 \mathrm{pS} \mu \mathrm{m}^{-2}$ at the distal end of the AIS at a distance of $55 \mu \mathrm{m}$ from the soma (Fig. $5 C$ ). Interestingly, unlike the AIS $\mathrm{Na}_{\mathrm{v}}$ currents, which are detectable only when ankyrin $\mathrm{G}$ binding is reduced (Kole et al., 2008), the comparison of patch recordings of $I_{\mathrm{M}}$ from cut-ends (lacking ankyrin $\mathrm{G}$ ) and the intact AIS showed no difference in the $I_{\mathrm{M}}$ amplitudes (unpaired $t$ test, $p=0.277 ; n=$ $8)$. The distribution of $K_{v} 7$ along the AIS could be fit with an exponential function ( $e$-fold increase, $\sim 13 \mu \mathrm{m} ; n=32$ ).

Together, these experiments reveal for the first time the gating properties of $\mathrm{M}$-current native to the axon, which have their highest conductance densities in the distal end of the AIS, $\sim 10$ fold higher compared with the soma.

\section{Local roles of $\mathrm{K}_{\mathrm{v}} 7$ channels in dendrites, soma, and axons}

To determine the global impact of a local high density of $\mathrm{K}_{\mathrm{v}} 7$ channels in the axon initial segment, we first applied XE-991 focally, via patch pipettes, to visually identified subcellular sites of L5 pyramidal axons using bright-field/fluorescence microscopy combined with somatic whole-cell recording (Fig. 6A). AIS K 7 channel block led to a significant increase in the somatically recorded ADP $(1.56 \pm 0.55$-fold increase; $n=6$; paired $t$ test, $p=$ 0.020; Fig. $6 B$ ). In comparison, bath application caused an approximately twofold increase (1.98 \pm 0.21 -fold increase; $n=18$; paired $t$ test, $p=0.000012$ ), suggesting that local AIS expression of $\mathrm{K}_{\mathrm{v}} 7$ channels may play a substantial role in counteracting the perisomatic depolarization during the ADP. Furthermore, focal 
application of XE-991 (10-20 $\mu \mathrm{M})$ had a clear location-dependent impact on the resting membrane potential (Fig. $6 C$ ). $\mathrm{K}_{\mathrm{v}} 7$ channel block at the apical dendrite, $\sim 100$ $\mu \mathrm{m}$ from the soma, changed neither the somatically recorded resting membrane potential nor the input resistance (average $V_{\mathrm{m}}$ change, $0.9 \pm 0.4 \mathrm{mV} ; R_{\mathrm{N}}$ change, $-0.3 \pm 3 \% ; n=6$; paired $t$ test, $p=0.079$ and $p=0.89$; Fig. $6 C$ ). XE-991 applied to the first node or the AIS, however, induced a $\sim 5 \mathrm{mV}$ depolarization of the resting membrane potential $\left(V_{\mathrm{m}}\right.$ change, $6.2 \pm 1.4 \mathrm{mV}, n=14$, paired $t$ test, $p=$ 0.00094 ; and $4.4 \pm 1.0 \mathrm{mV}, n=6$, paired $t$ test, $p=0.014)$. Puffing solution alone (i.e., without XE-991) had no impact on the resting membrane potential when applied to the AIS $(0.3 \pm 0.75 \mathrm{mV}, n=5$, $p=0.14$; Fig. $6 C$ ). In comparison, bath application of 10-20 $\mu \mathrm{M}$ XE-991 depolarized the resting membrane potential by on average $3.1 \pm 0.4 \mathrm{mV}$ (paired $t$ test, $p=$ $0.000035 ; n=28$; Fig. $6 C$ ) and decreased the resting conductance by $\sim 6 \mathrm{nS}$ (control, $36.8 \pm 2.1 \mathrm{nS}$; XE-991, $30.3 \pm 2.9 \mathrm{nS}$; $n=30$; paired $t$ test, $p=0.000013$ ).

The resting membrane depolarization with focal XE-991 application to the AIS, a region only $45 \mu \mathrm{m}$ in length $\left(<1 \mathrm{nS} \mathrm{K}_{\mathrm{v}} 7\right.$ conductance at rest) was surprisingly similar in magnitude compared with bath application of XE-991 ( $\sim 4 \mathrm{mV})$. We hypothesized that the persistent $\mathrm{Na}^{+}$current in part mediates the depolarizing drive by amplifying the membrane potential depolarization during $\mathrm{K}_{\mathrm{v}} 7$ channel block. Indeed, in the presence of TTX the XE-991-induced resting membrane depolarization was significantly reduced (TTX + XE991, $1.7 \pm 0.3 \mathrm{mV} ; n=5$; unpaired $t$ test vs XE-991 alone, $p=$ 0.0044; Fig. 6C). These data suggest that AIS $\mathrm{K}_{\mathrm{v}} 7$ channels prevent subthreshold activation of $\mathrm{Na}_{\mathrm{v}}$ current.

Interestingly, when applying XE-991 to the AIS the change in resting membrane potential was sufficient to reach action potential threshold and generate spontaneous firing in $61 \%$ of the cells ( 14 of 23 cells; Fig. 6D). Long-lasting periods of unstable membrane potential fluctuations $(\sim 10 \mathrm{mV})$ persisted for several minutes and were associated with spontaneous action potential firing rates (average rate, $3.6 \pm 0.8 \mathrm{~Hz} ; n=17$; Fig. $6 E$ ). These large membrane potential fluctuations and periods of spontaneous firing, similar to observations in the CA1 pyramidal neuron (Shah et al., 2008), were also observed in the presence of blockers for inhibitory and excitatory synapses (bicuculline, gabazine, and DNQX; $n=3$ ), in accordance with the idea that these are generated by intrinsic conductances. A power spectrum analysis of the intrinsic spontaneous action potential firing periods showed that the peak of activity occurred at frequencies of $\sim 4$ and $9 \mathrm{~Hz}$, correlating with either high-frequency oscillatory bursts or regular action potential firing $(n=6$; Fig. $6 F)$. To test whether block of $\mathrm{K}_{\mathrm{v}} 7$ channels by XE-991 unmasks a persistent component of axonal sodium currents (Golomb et al., 2006; Yue and Yaari, 2006), we bath applied $5 \mu \mathrm{M}$ riluzole, a nonspecific blocker with high sensitivity for the persistent sodium current (Urbani and Belluzzi, 2000). Riluzole did not change the amplitude of single action potentials compared with XE-991 alone (XE-991, $97.4 \pm$ $1.5 \mathrm{mV}$; XE-991 plus riluzole, $96.3 \pm 3.4 \mathrm{mV} ; n=6$; paired $t$ test, $p=0.70$; Fig. $6 G)$. However, the XE-991-induced increase in the ADP was reduced to control values in the presence of riluzole (XE-991, 174.1 $\pm 25.4 \%$; XE-991 plus riluzole, $114.9 \pm 17.7 \%$; $n=6$; repeated-measures ANOVA, $p=0.0043$; Fig. $6 G$ ). In these recordings, one neuron developed sustained action potential firing after XE-991 application, and bath application of $5 \mu \mathrm{M}$ riluzole reduced the spontaneous action potentials after $\sim 15 \mathrm{~min}$ (Fig. 6H)

Together, these data indicate that AIS $\mathrm{K}_{\mathrm{v}} 7$ channels exert hyperpolarizing stabilizing effects upon the resting membrane potential, thereby preventing activation of persistent $\mathrm{Na}^{+}$current activated at subthreshold potentials and restraining spontaneous firing.

\section{$\mathrm{K}_{\mathrm{v}} 7$ channel activation at the resting membrane potential augments propagating axonal action potentials}

Do $\mathrm{K}_{\mathrm{v}}$ 7.2/7.3 channels concentrated at nodes of Ranvier also have an attenuating impact on action potential propagation? Direct intracellular recordings from central nodes $(\sim 1 \mu \mathrm{m}$ in length) are difficult to achieve with patch pipettes $(\sim 1 \mu \mathrm{m}$ tip diameter). As an alternative, we examined the role of $\mathrm{K}_{\mathrm{v}} 7$ in nodal action potentials by using dual pipette recordings from the soma and axon cut-ends (a distance of 130-650 $\mu \mathrm{m}$ from the soma), evoking action potentials at the soma and using bath application of XE-991 (Fig. 7A). The change in the ADP appeared highly location dependent (two-way ANOVA, $p=0.0004 ; F=19.82 ; n=9$ ). While the ADP significantly increased at the soma (control, 
A

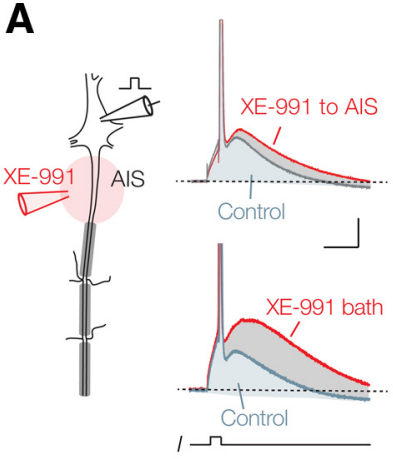

B
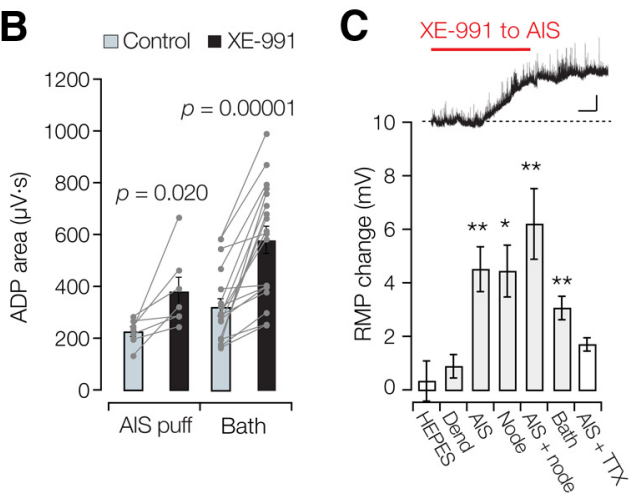

D
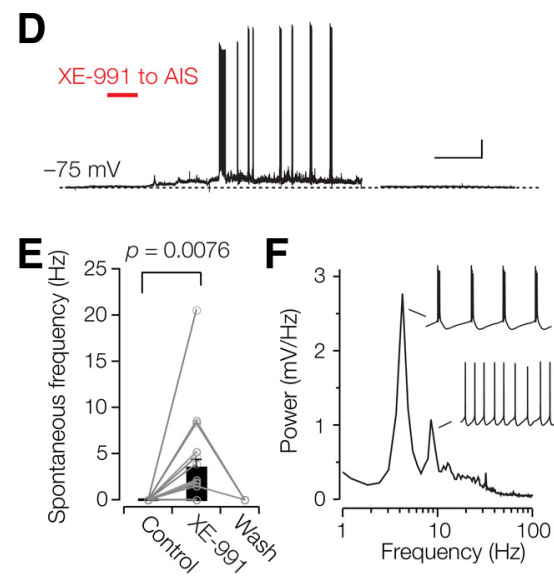

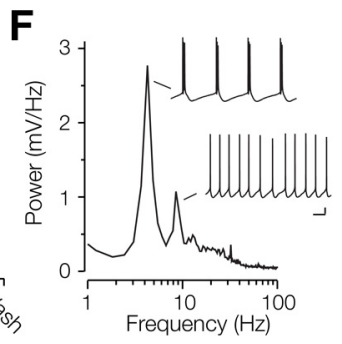

G
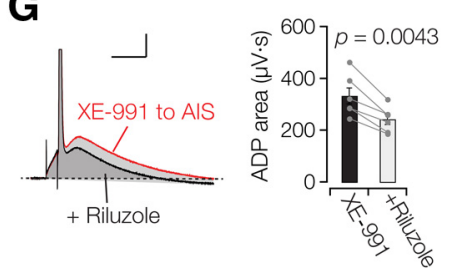

H

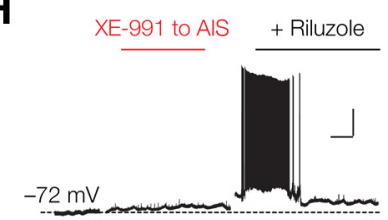

Figure 6. Axonal $\mathrm{K}_{\mathrm{v}} 7$ channels maintain resting membrane potential stability. $A$, Left, Schematic drawing of the drug application (red) and recording pipette arrangement (black). In this example, XE-991 was focally applied to the AIS. Right, Example voltage recordings before (gray) and after XE-991 application (red) locally to the AIS (right top) or in the bath (right bottom) show an augmentation of the ADP. Calibration: $10 \mathrm{~ms}, 10 \mathrm{mV}$. $\boldsymbol{B}$, Line and scatter plots of the individual data reveal an increase in the ADP after local XE-991 application to the AIS $(n=6)$ or global block in the bath $(n=18)$. C, Population data of the resting membrane potential change for the different locations and solutions. HEPES, Control solution without XE-991 to the AIS; Dend, XE-991 to the dendrite; AIS, XE-991 to the axon initial segment; Node, XE-991 to the node; AIS + first node, XE-991 to the AIS and node; Bath, XE-991 in the bath; AIS + TTX, XE-991 to the axon initial segment in the presence of $1 \mu \mathrm{MTTX} .{ }^{*} p<0.001,{ }^{*} p<0.05$. Data represent the mean \pm SEM. Inset, Focal AIS application of XE-991 depolarized the resting membrane potential. Calibration: $1 \mathrm{mV}$, $1 \mathrm{~min}$. D, Example of a recording in which $20 \mu \mathrm{M}$ XE-991 caused spontaneous firing. A 20 min period before washout was blanked for clarity. Calibration: $4 \mathrm{~min}, 10 \mathrm{mV}$. E, Summary data for the 17 experiments in which 10-20 $\mu \mathrm{m}$ was focally applied to the AIS. Washout was tested in three experiments. $\boldsymbol{F}$, Power spectrum of the spontaneous action potential firing rate during AIS $\mathrm{K}_{\mathrm{v}} 7$ channel block. Action potential frequencies ranged between $\sim 4$ and $38 \mathrm{~Hz}(n=6)$. Calibration: $0.1 \mathrm{~s}, 10 \mathrm{mV}$. G, After local XE-991 application to the AIS blocking the persistent sodium current by bath application of $5 \mu \mathrm{m}$ riluzole decreased the ADP (left). Calibration: $10 \mathrm{mV}, 10 \mathrm{~ms}$. Population data for the changes of the ADP area during XE-991 application to the AIS and in the presence of riluzole (right). The XE-991 data is the same as in $\boldsymbol{B}$. $\boldsymbol{H}$, Recording in which XE-991 puffing to the AIS caused spontaneous firing and application of $5 \mu \mathrm{m}$ riluzole abolished the spontaneous APs. Gaps in the recording are blanked for clarity. Calibration: $2 \mathrm{~min}, 20$ $\mathrm{mV}$.

$279.0 \pm 29.9 \mu \mathrm{V} \cdot \mathrm{s} ; \mathrm{XE}-991,378.0 \pm 36.3 \mu \mathrm{V} \cdot \mathrm{s}$; Bonferroni correction, $t=5.96, p=0.0039 ; n=9)$, the voltage-time integral was not affected in distal regions of the axon (control, $119.7 \pm$ $22.7 \mu \mathrm{V} \cdot \mathrm{s}$; XE-991, $114.0 \pm 21.6 \mu \mathrm{V} \cdot \mathrm{s}$; Bonferroni correction, $t=0.34, p=0.56 ; n=9$; Fig. $7 B$ ). Interestingly, the action potential amplitude change, measured as the threshold to peak difference, was also location dependent (two-way ANOVA, $p=$ $0.0002, F=22.81 ; n=9$ ) but in an opposite manner. XE-991 led to a significant action potential amplitude reduction in the axon (average reduction, $-13.9 \mathrm{mV}$; Bonferroni correction, $t=7.31$, $p=0.0021 ; n=9$; Fig. $7 B)$ but not in the soma $(-1.0 \mathrm{mV}$ reduction; Bonferroni correction, $t=0.59, p=0.58 ; n=9)$.

As a comparison, we also made double whole-cell recordings from soma and axon endings cut at the AIS tip (35-60 $\mu \mathrm{m}$ from the soma; $n=5$; Fig. $7 C$ ). Bath application of $10 \mu \mathrm{M}$ XE-991 depolarized the action potential voltage threshold in the AIS by $\sim 3 \mathrm{mV}$ (control, $-54.9 \pm 2.6 \mathrm{mV}$; XE$991,-51.9 \pm 2.3 \mathrm{mV}$; paired $t$ test, $p=$ 0.022; $n=5$; Fig. 7C). Furthermore, $\mathrm{K}_{\mathrm{v}} 7$ channel block caused only a small reduction in the AIS action potential amplitude (control, $101.8 \pm 3.2 \mathrm{mV}$; XE-991, $96.7 \pm$ $3.9 \mathrm{mV} ; p=0.043 ; n=5)$ and the peak of the rate of rise (control, $1.97 \pm 0.2 \mathrm{kV} \mathrm{s}^{-1}$; XE-991, $1.6 \pm 0.15 \mathrm{kV} \mathrm{s}^{-1} ; p=0.0017$; $n=5)$. While in these recordings the voltage threshold at the soma did not change $(-0.5 \pm 0.7 \mathrm{mV} ; p=0.432 ; n=5)$, higher concentrations of XE-991 $(20 \mu \mathrm{M})$, causing a larger fractional block of $\mathrm{K}_{\mathrm{v}} 7$ channels (Fig. 3D), significantly depolarized the threshold $(+2.6 \pm 0.9 \mathrm{mV}$; paired $t$ test, $p=0.019 ; n=12$ ). On the other hand, simultaneous whole-cell recordings from soma and distal dendrites $(>400$ $\mu \mathrm{m}$ from the soma) revealed that XE-991 increased the backpropagating action potential amplitude by on average $6.5 \pm 2.3$ $\mathrm{mV}(p=0.043, n=4$; Fig. $7 D)$. Plotting the action potential amplitude change in the presence of XE-991 versus all recording locations showed that $\mathrm{K}_{\mathrm{v}} 7$ channels differentially affect action potential propagation into dendritic and axonal regions (Fig. 7E). A depolarized voltage threshold and amplitude reduction of fast sodium action potentials is inconsistent with block of an outward current and the experimentally measured $I_{\mathrm{M}}$ activation kinetics near action potential threshold ( $\sim 40 \mathrm{~ms}$ at $-55 \mathrm{mV}$; Figs. 4,5$)$ are also too slow to affect threshold behavior. Therefore, these data suggest that $\mathrm{K}_{\mathrm{v}} 7$ channels open at rest rather regulate the $\mathrm{Na}_{\mathrm{v}}$ channel availability by setting the resting potential.

\section{Membrane potential regulation of propagating axonal action potentials} The amplitude of the conducting axonal action potential is known to critically depend on the membrane potential (Waxman et al., 1995; Shu et al., 2006; Kole et al., 2007). Furthermore, recent studies have shown that in central axons the midpoint of steady-state $\mathrm{Na}_{\mathrm{v}}$ channel inactivation is near $-80 \mathrm{mV}$ with a slope of $\sim 9 \mathrm{mV}$ (Hu et al., 2009; SchmidtHieber and Bischofberger, 2010), predicting that even small changes near the resting membrane potential $(-77 \mathrm{mV})$ influence nodal $\mathrm{Na}_{\mathrm{v}}$ channel availability. To test that prediction, we quantitatively examined action potential amplitudes while varying resting potentials between -110 and $-40 \mathrm{mV}$ using local DC injection into the axon (Fig. $8 A-C$ ). Action potentials were then activated by somatic current injection, and recorded at the soma and axon, at a distance of between 150 and $250 \mu \mathrm{m}$ from the soma. Both somatic and axonal action potentials showed two distinct components in the first time derivative. The first component reflects invasion from the antidromically propagating initial segment action potential and the second generated by local $\mathrm{Na}_{\mathrm{v}}$ channels (Kole and Stuart, 2008). By using Boltzmann fits to the 
individual component amplitudes at the soma, the first component was found to inactivate at a midpoint voltage of $-55.7 \pm 0.9 \mathrm{mV}(n=8)$, significantly more hyperpolarized compared with the second somatodendritic component $(-53.7 \pm 0.9 \mathrm{mV}$; paired $t$ test, $p=0.027$; $n=8$; Fig. $8 B$ ). In the axon, the first component showed a midpoint voltage of $-52.8 \pm 2.3 \mathrm{mV}(n=5)$, while the second component inactivated at $-76.5 \pm 2.1$ $\mathrm{mV}(n=5)$. These data suggest that steady-state inactivation of $\mathrm{Na}_{\mathrm{v}}$ channels occurs at much more hyperpolarized potentials in nodal domains. The action potential amplitudes in the axon had a midpoint voltage a few millivolts more depolarized from the resting membrane potential $[-71.0 \pm 2.4 \mathrm{mV}(n=5$, axons $)$ with a slope of $5.5 \pm 0.3 \mathrm{mV}(n=5)$; Fig. $8 C$ ]. In contrast, somatic action potentials had a $20 \mathrm{mV}$ more depolarized midpoint of inactivation $(-50.2 \pm 0.9 \mathrm{mV} ; n=10$; unpaired $t$ test, $\left.p=5.7 \times 10^{-12}\right)$ with a shallower slope $(6.8 \pm 0.4 \mathrm{mV}$; unpaired $t$ test, $p=0.033)$. Finally, to determine whether the depolarization of the resting potential causes the axonal action potential amplitude change in XE-991, we corrected the local depolarization in the presence of $10 \mu \mathrm{M}$ XE-991 $(+2.1 \pm 0.3$ $\mathrm{mV} ; n=4)$ by applying negative DC injections into the axon $[\sim 10 \mathrm{pA}$ nullified the resting potential difference with control $(-0.1 \pm 0.3 \mathrm{mV})]$. The membrane potential correction fully restored the action potential amplitudes (one-way repeated-measures ANOVA, $p=0.0013, F=24.6$; Fig. $8 D$ ).

These data show that the propagating axonal action potential is highly sensitive to the resting membrane potential, in part influenced by nodal heterotetrameric $\mathrm{K}_{\mathrm{v}} 7.2 / 7.3$ channels that are open at rest.

Spatial heterogeneity of $\mathrm{K}_{\mathrm{v}} 7$ conductances in soma and axons To quantitatively examine how nodal $\mathrm{K}_{\mathrm{v}} 7.2 / 7.3$ channels interact with $\mathrm{Na}_{\mathrm{v}}$ channel availability, we generated a Hodgkin-Huxley model of the $\mathrm{K}_{\mathrm{v}} 7$ conductance constrained by the experimentally recorded voltage and time dependence of the currents (Figs. 4, $9 A$; see Materials and Methods). This conductance model, based on a single activation gate, was subsequently implemented into a multicompartmental model of a morphologically reconstructed L5 pyramidal neuron with an axon (see Materials and Methods). Using voltage-clamp protocols similar to the experimental voltage-clamp experiments, the simulated whole-axon currents resembled the experimentally obtained currents, both in amplitude and their time course (Fig. 9B). Several key characteristics of $\mathrm{K}_{\mathrm{v}} 7$-mediated excitability were captured in this model. In agreement with our experimental observations, a global reduction of $\bar{g}_{M}$ by $60 \%$ (mimicking $10 \mu \mathrm{M}$ XE-991; Fig. 3D) caused a spatially uniform $\sim 3 \mathrm{mV}$ depolarization of the resting membrane potential, increased the afterdepolarization, and led to multiple action potentials at high frequency (Fig. 9C,D). The change in resting potential with $\bar{g}_{M}$ reduction was nonlinear and in part dependent on subthreshold $\mathrm{Na}_{\mathrm{v}}$ channel activation since removing $\mathrm{Na}_{\mathrm{v}}$ from the model reduced the resting membrane potential depolarization (Fig. 9D).

Next, to understand the differences in the $\mathrm{K}_{\mathrm{v}} 7$ regulation of action potentials between compartments we plotted the time course of $g_{\mathrm{M}}$ during the action potential in the soma and in a node of Ranvier at a distance of $\sim 600 \mu \mathrm{m}$ from the soma (Fig. 10A). At the resting membrane potential $(-78 \mathrm{mV}), \bar{g}_{M}$ has a uniform open probability $\left(P_{\mathrm{o}}\right)$ of 0.04 . At the soma, $\bar{g}_{M}$ increased rapidly during the rising phase of the action potential, peaked with a $\sim 10$ ms delay, and slowly returned to the resting conductance shaped by the slow $I_{M}$ deactivation kinetics. In comparison, however, the nodal action potential (250 $\mu$ s in half-width) recruited $g_{\mathrm{M}}$ less efficiently. The maximum $P_{\mathrm{o}}$ was 0.065 , and subsequently deactivated rapidly due to the large afterhyperpolarization mediated by axonal $\mathrm{K}_{\mathrm{v}} 1$ (Fig. 10A). The compartmental differences in $g_{\mathrm{M}}$ activation were further explored by examining the accumulation of activation by repetitive action potential generation $(170 \mathrm{~Hz})$ during a $30 \mathrm{~ms}$ lasting depolarization. Figure $10 \mathrm{~B}$ shows the resulting maximum $g_{M}$ for each action potential as a function of location along the dendrosomatic-axonal axis. While $g_{\mathrm{M}}$ increased progressively in the perisomatic region as a function of action potential number (2.2-fold $P_{\mathrm{o}}$ increase), consistent with the rapid repolarization and large afterhyperpolarzation of the nodal action potential, $g_{\mathrm{M}}$ showed little increase in the node (1.2fold). Finally, we assessed in the model the overlap between the 
A
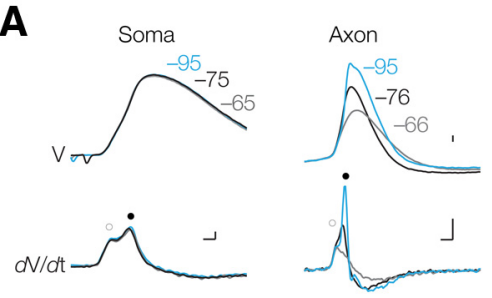

B

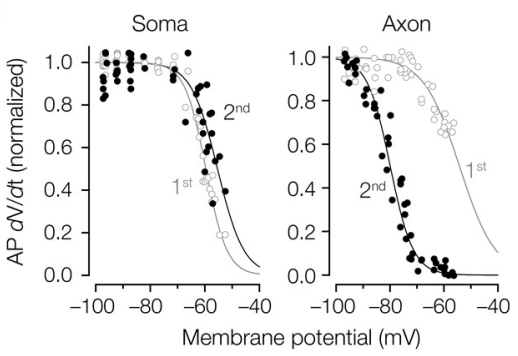

C

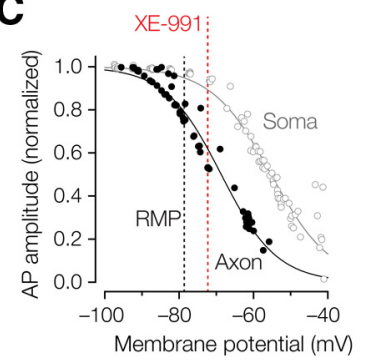

D
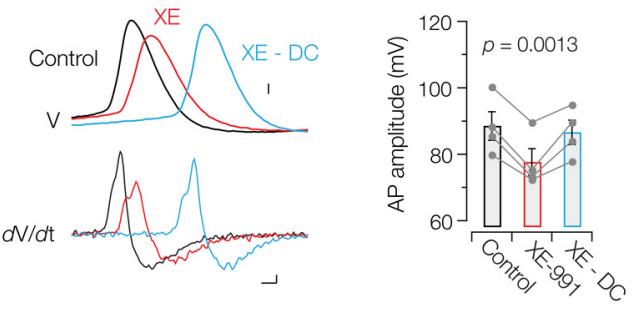

Figure 8. Voltage dependence of action potentials at somatic and axonal locations. $A$, Top, Voltage dependence of the somatic (left) and axonal action potential amplitude (right) assessed by applying local positive (gray) and negative holding currents (blue). Action potentials evoked from the resting membrane potential (RMP) are indicated in black. Calibration: $10 \mathrm{mV}$. Bottom, First derivatives of the voltage corresponding to the above-displayed action potentials. Circles indicate the first (open circle) and second peaks (closed circle), respectively. Calibration: $100 \mu \mathrm{s}, 0.1 \mathrm{kV} \mathrm{s}^{-1}$ (left); $100 \mu \mathrm{s}, 0.5 \mathrm{kV} \mathrm{s}^{-1}$ (right). B, Peak amplitudes of the first and second component of the time derivative separately fit with Boltzmann equations. Note the hyperpolarized inactivation at axonal sites compared with the soma. C, Data from two example recordings reveal a $\sim 20 \mathrm{mV}$ difference in the midpoint of inactivation of action potential amplitudes between axons (black) and soma (gray). Data were fit with Boltzmann equations (lines). The resting membrane potential in control (black) and in 10-20 $\mu \mathrm{m} \mathrm{XE-991} \mathrm{(red)} \mathrm{are} \mathrm{indicated} \mathrm{as} \mathrm{dotted} \mathrm{lines.} \mathrm{D,} \mathrm{The}$ reduced axonal action potential amplitude after XE-991 application can be recovered by direct negative current injections (top, blue). Calibration: $10 \mathrm{mV}$. Corresponding differentiated voltage of the action potentials (bottom) and summary data (mean \pm SEM) for four similar experiments (right). Calibration: $100 \mu \mathrm{s}, 0.1 \mathrm{kV} \mathrm{s}^{-1}$.

$I_{\mathrm{M}}$-mediated resting membrane depolarization and local sodium channel inactivation $\left(h_{\mathrm{Na}}\right)$. The midpoints of $\mathrm{Na}_{\mathrm{v}}$ channel inactivation in soma, AIS, and axon were implemented based on available experimental data (Fig. 10C; see Materials and Methods). Reducing $g_{\mathrm{M}}$ in the model by $70 \%$, mimicking XE-991 application, uniformly raised the resting membrane potential by $\sim 5 \mathrm{mV}$ and consequently reduced both the forward-propagating action potential rate of rise and the amplitude $(15 \mathrm{mV}$ reduction; Fig. 10D). In contrast to the nodal action potential, the somatic amplitude was largely maintained ( $3 \mathrm{mV}$ reduction; Fig. $10 \mathrm{D})$, which is consistent with the experimental results (Figs. 7, 8).

In conclusion, the results of the computational model and the experimental work suggest that due to the combined effect of the passive voltage attenuation in central myelinated axons, the active high-pass filtering of nodal action potentials by $\mathrm{K}_{\mathrm{v}} 1$ and the compartmentalization of steady-state $\mathrm{Na}_{\mathrm{v}}$ channel inactivation, the $\mathrm{K}_{\mathrm{v}} 7.2$ and $\mathrm{K}_{\mathrm{v}} 7.3$ coclustering with $\mathrm{Na}_{\mathrm{v}}$ channels in the nodal axolemma will primarily influence their availability.

\section{Discussion}

We present here the first biophysical characterization and functional analysis of the $\mathrm{M}$-current in a myelinated CNS axon. The axonal M-current, mediated by $\mathrm{K}_{\mathrm{v}} 7.2 / 7.3$ (KCNQ2/KCNQ3) heteromultimers, is $\sim 4 \%$ in the open state at the resting membrane potential, and activates rapidly and monoexponentially with time constants between 15 and $50 \mathrm{~ms}$. In contrast to the well established attenuating effects of $I_{\mathrm{M}}$ on excitability in the perisomatic region, coclustering of $\mathrm{K}_{\mathrm{v}} 7.2 / 7.3$ with $\mathrm{Na}_{\mathrm{v}}$ channels in nodes of Ranvier primarily increases the availability of the tran- sient $\mathrm{Na}_{\mathrm{v}}$ current, thereby accelerating the action potential upstroke.

In the rat peripheral sciatic nerve, most small- and medium-sized axons $(<6 \mu \mathrm{m})$ express both $\mathrm{K}_{\mathrm{v}} 7.3$ and $\mathrm{K}_{\mathrm{v}} 7.2$ subunits in their nodes of Ranvier, while the largest axons $(>10 \mu \mathrm{m})$ express mostly homomeric $\mathrm{K}_{\mathrm{v}} 7.2$ channels (Schwarz et al., 2006). The present results corroborate and extend those observations by showing that central myelinated neocortical axons, ranging between 1 and $3 \mu \mathrm{m}$ in diameter before entering the white matter, were nearly always immunoreactive for both $\mathrm{K}_{\mathrm{v}} 7.2$ and $\mathrm{K}_{\mathrm{v}} 7.3$ in the nodes of Ranvier. The limited diversity of $\mathrm{K}_{\mathrm{v}}$ channels in axons, compared with the somatodendritic region, allowed isolation of $\mathrm{K}_{\mathrm{v}} 7$ by blocking the 4-AP-sensitive fast-activating $\mathrm{K}_{\mathrm{v}} 1$ $\left(\mathrm{K}_{\mathrm{v}} 1.1 / 1.2\right)$ channels, which are densely expressed in L5 axons (Kole et al., 2007; Shu et al., 2007; Hallermann et al., 2012) and clustered in the AIS and juxtaparanodal regions (Poliak and Peles, 2003; Kole and Stuart, 2012). The remaining current has the pharmacological profile of $\mathrm{K}_{\mathrm{v}} 7.21$ 7.3 heteromers. First, the pharmacological sensitivity to XE-991 implicates the $\mathrm{K}_{\mathrm{v}} 7$ family. Second, the hyperpolarizing shift of the voltage dependence, increased current density, and slowed deactivation in the presence of retigabine implicate $\mathrm{K}_{\mathrm{v}}$ 7.2-7.5. Third, the TEA block results are inconsistent with $\mathrm{K}_{\mathrm{v}} 7.2, \mathrm{~K}_{\mathrm{v}} 7.3$, or $\mathrm{K}_{\mathrm{v}} 7.5$ homomers (or $\mathrm{K}_{\mathrm{v}} 7.3 / 7.5$ heteromers), and exactly fit those obtained in $I_{\mathrm{M}}$ in superior cervical ganglion neurons from adult rats (Hadley et al., 2003), from heterologous coexpression of $\mathrm{K}_{\mathrm{v}} 7.2$ and $\mathrm{K}_{\mathrm{v}} 7.3$ as separate cDNAs (Wang et al., 1998; Hadley et al., 2000; Shapiro et al., 2000), or as concatamers (Hadley et al., 2003). These results indicate that at least $80-90 \%$ of the L 5 axonal $\mathrm{M}$-current is mediated by $\mathrm{K}_{\mathrm{v}} 7.2 / 7.3$ heteromultimers, although we cannot exclude a small contribution of alternative combinations and non- $\mathrm{K}_{\mathrm{v}} 7$ channels.

Interestingly, we found that activation and deactivation kinetics were faster $\left(\sim 15 \mathrm{~ms}\right.$ at $28 \mathrm{mV}$, at $\left.35^{\circ} \mathrm{C}\right)$ compared with previous reports of the native $\mathrm{M}$-current in superior cervical ganglion neurons or heterologous expressed $\mathrm{K}_{\mathrm{v}} 7.2 / 7.3$ heteromeric channels (Wang et al., 1998, 2000; Selyanko and Brown, 1999; Pan et al., 2001; Selyanko et al., 2001), and had mostly a monoexponential rising phase. Whether this reflects alternative splice variants of KCNQ2 (Pan et al., 2001), post-translational modification, or protein-protein interaction specific to the AIS and nodes remains to be determined. One constraint is that our recordings from distal axonal sites are primarily from cut-ends, which may suffer from damage, voltage-gated channel reorganization, or cytoskeletal rearrangements (Bradke et al., 2012). However, since our voltage-clamp data from the intact AIS were very similar in kinetics and voltage dependence compared with whole-axon recordings, the presumed ion channel modifications due to axotomy may have had a minimal impact on axonal $\mathrm{K}_{\mathrm{v}} 7$ channels.

Patch recordings from the distal end of the AIS also enabled us to estimate a peak conductance density of $\mathrm{K}_{\mathrm{v}} 7$ as $\sim 150 \mathrm{pS} \mu \mathrm{m}^{-2}$. 
In comparison, the somatic density was $>10$-fold lower, $12 \mathrm{pS}$ $\mu \mathrm{m}^{-2}$ (equivalent to $\sim 1$ channel $\mu \mathrm{m}^{-2}$ ), which is in reasonable agreement with previous measurements and numerical simulations (2-6 pS $\mu \mathrm{m}^{-2}$; Chen and Johnston, 2004; Gu et al., 2005; Lawrence et al., 2006; $\mathrm{Hu}$ et al., 2007). Interestingly, in sciatic nerve nodes the maximal conductance density of the $I_{\mathrm{Ks}}$ was estimated at $18.8 \mathrm{nS} \mathrm{pF}^{-1}$ or $188 \mathrm{pS} \mu \mathrm{m}^{-2}$ (assuming $0.01 \mathrm{pF}$ $\mu \mathrm{m}^{-2}$; Röper and Schwarz, 1989). The similarity to our peak conductance estimation of $I_{\mathrm{M}}$ in the distal end of the AIS adds to the considerable existing evidence of molecular similarity in the composition of AIS and nodes. While both $\mathrm{Na}_{\mathrm{v}} 1.6$ and $\mathrm{K}_{\mathrm{v}} 7$ channels are anchored via ankyrin $\mathrm{G}$ to the actin-spectrin filament network (Pan et al., 2006; Hill et al., 2008; Cooper, 2011), the $\mathrm{K}_{\mathrm{v}} 7$ peak conductance density is $\sim 40$ fold smaller compared with AIS peak $\mathrm{Na}_{\mathrm{v}}$ conductance density $\left(\sim 7000 \mathrm{pS} \mu \mathrm{m}^{-2}\right.$; Hallermann et al., 2012). How these specific ratios of $\mathrm{Na}_{\mathrm{v}} / \mathrm{K}_{\mathrm{v}} 7$ channels are established and maintained is not well understood. Fluorescence recovery after photobleaching experiments indicates that ankyrin $\mathrm{G}$ interacts more weakly with the conserved C-terminal binding domains of $\mathrm{K}_{\mathrm{v}} 7.2 / 7.3$ subunits (Pan et al., 2006) than with neurofascin (Zhang and Bennett, 1998). Relatively weak binding may make $\mathrm{K}_{\mathrm{v}} 7$ channels poor competitors with $\mathrm{Na}_{\mathrm{v}}$ subunits and other ankyrin $G$ ligands. Nonetheless, the distal AIS-predominant $\mathrm{K}_{\mathrm{v}}$ 7.2/7.3 labeling and conductance profile contrasts markedly with the distribution of ankyrin G. Molecular mechanisms for such subcompartmentalization within the AIS are unknown.

One of the main findings of our study is the identification of a new physiological significance of $\mathrm{Na}_{\mathrm{v}} / \mathrm{K}_{\mathrm{v}} 7$ coclustering. In the dendrites, soma, and AIS, $I_{\mathrm{M}}$ accumulates significant outward current during action potential generation and consequently affects spike frequency accommodation and network oscillations (Yue and Yaari, 2004; Lawrence et al., 2006; Safiulina et al., 2008; Brown and Passmore, 2009; Leão et al., 2009). Also in isolated single nodes from peripheral sciatic axons, direct current injection evokes more action potentials when the $\mathrm{K}_{\mathrm{v}} 7$ current is pharmacologically blocked, suggesting a role in spike frequency accommodation (Schwarz et al., 2006). Our experimental and computational data show that, due to the cable properties and associated voltage attenuation in the central L5 axons (length constant, $0.6 \mathrm{~mm}$; Kole et al., 2007), the propagating axonal action potential, when initiated in the AIS, will minimally activate nodal $\mathrm{K}_{\mathrm{v}} 7$ in the subthreshold voltage range. In these axons, the juxtaparanodal activation of $\mathrm{K}_{\mathrm{v}} 1$ current rapidly repolarizes the action potential, conferring an active high-pass filtering and leading to a brief half-width duration $(<400 \mu \mathrm{s})$, causing minimal afterdepolarization. Passive voltage attenuation and local $\mathrm{K}_{\mathrm{v}} 1$ activation in central axons therefore leads to a limited recruitment of $I_{\mathrm{M}}$ and minimally charges the nodal membrane resistance in the subthreshold range during propagating action potentials.

Rather than attenuating subthreshold depolarization, the high density of nodal $\mathrm{K}_{\mathrm{v}}$ 7.2/7.3 channels plays a major role in
A
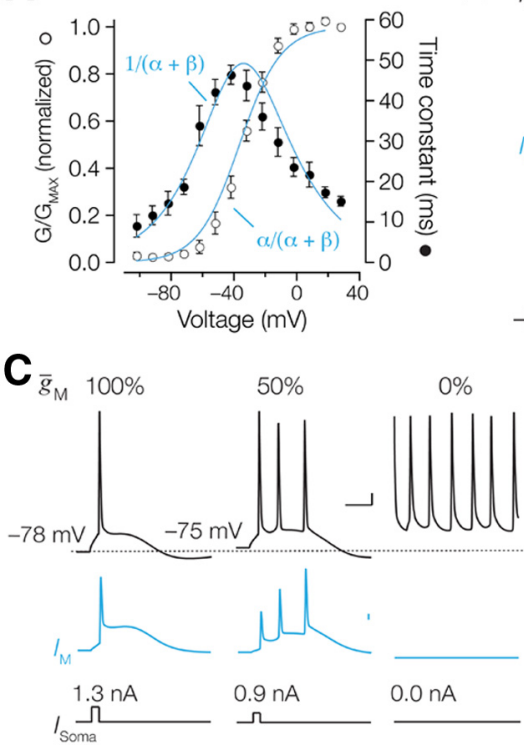

B

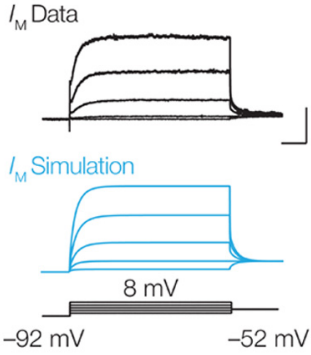

D $\circ$ Data

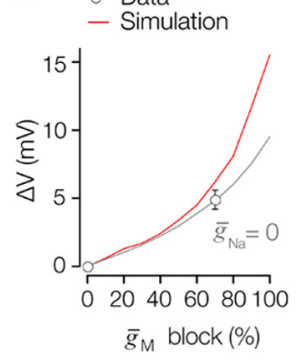

Figure 9. Simulation of $I_{\mathrm{m}}$ in the NEURON model. $\boldsymbol{A}$, Steady-state activation (open circles) and time constants (closed circles) of axonal $I_{\mathrm{m}}$ fit with a Hodgkin-Huxley model (blue). $\boldsymbol{B}$, Top, average of five experimental whole-axon recordings. Middle, Simulated $\mathrm{K}_{\mathrm{v}} 7$ currents activated during a single-electrode voltage-clamp simulation (SEClamp) in NEURON (blue). Bottom, Voltage command protocol for simulation and experiments. Calibration: $100 \mathrm{~ms}, 100$ pA. C, Reducing the $\mathrm{K}_{\mathrm{v}} 7$ peak conductance density by $50 \%$ (middle) and $100 \%$ (right) in the model replicates the experimental XE-991 block (compare Figs. 6 and 7). Blue traces represent the activated $I_{\mathrm{m}}$ for the different conditions. Calibration: $10 \mathrm{mV}, 10 \mathrm{~ms}$ (top); $1 \mathrm{~mA} / \mathrm{cm}^{2}$ (middle). D, Summary data showing the effect of reducing $\bar{g}_{M}$ on the simulated resting membrane potential in control conditions (red line) and without sodium conductance (gray line) overlaid with experimentally observed resting potential change (circles). Symbols represent the mean \pm SEM.
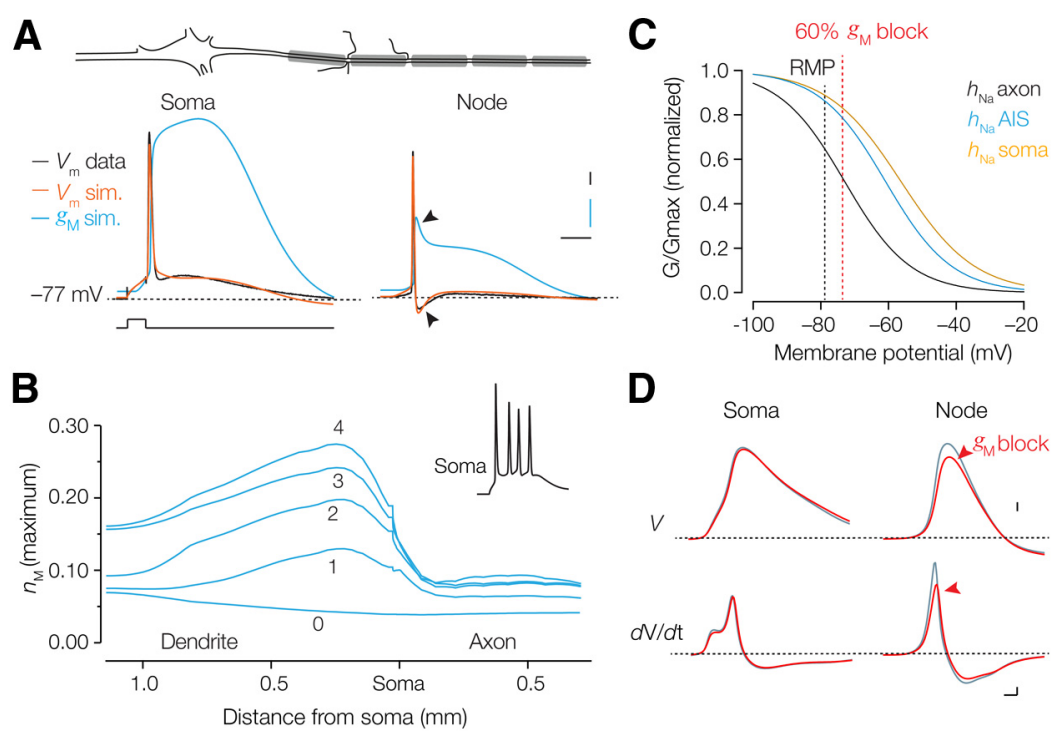

Figure 10. Voltage and site dependence of $\mathrm{K}_{\mathrm{v}} 7$ activation and sodium channel inactivation. $A$, Top, Schematic of the neuron model. Bottom, Voltage traces of the soma and a node ( $620 \mu \mathrm{m}$ distance from the soma). Recorded (black) and simulated (orange) action potential waveforms at soma and node overlaid with the corresponding time course of $g_{\mathrm{M}}$ (blue). Arrows at the axonal traces indicate the strong afterhyperpolarization and reduction of $g_{\mathrm{M}}$ due to $\mathrm{K}_{\mathrm{v}} 1$ activation. Calibration: $5 \mathrm{~ms}, 10 \mathrm{mV}, 1 \%$ (blue). $\boldsymbol{B}$, Space plot of the maximum $g_{\mathrm{M}}$ activation along the dendrosomatic-axonal axis during the resting membrane potential $(0)$ and during action potentials (1-4). Inset, Voltage-time plot of the action potentials $(170 \mathrm{~Hz})$ in the soma. $g_{M}$ has the highest degree of activation in the proximal dendrite, but the least in the axon. C, Steady-state sodium inactivation curves used for soma (black), AIS (blue), and axon (orange). Dotted vertical lines indicate the resting membrane potential (black) and $70 \%$ block of $g_{\mathrm{M}}$ (red). $\boldsymbol{D}$, Simulated somatic and nodal action potentials in control (gray) and during $70 \%$ block of $g_{\mathrm{M}}(\mathrm{red})$. Note the selective reduction in action potential rate of rise and amplitude at the node. Calibration: $10 \mathrm{mV}$ (top); $100 \mathrm{~V} / \mathrm{s}, 100 \mu \mathrm{s}$ (bottom). 
setting the resting membrane potential and indirectly influences the steady-state availability of $\mathrm{Na}_{\mathrm{v}}$ channels. The basis for the resting membrane potential in central myelinated axons is incompletely known, but in the periphery is determined by a combination of the depolarizing drive from persistent $\mathrm{Na}^{+}$and $\mathrm{HCN}$ channels and the outward currents generated by nodal $\mathrm{K}_{\mathrm{v}} 7$ and internodal $\mathrm{Na}^{+} / \mathrm{K}^{+}$pumps (Thomas, 1972; Stys et al., 1993; Waxman et al., 1995). Increasing the action potential peak amplitude by membrane hyperpolarization without changing the half-width may be predicted to enhance $\mathrm{Ca}^{2+}$ current influx at the presynaptic terminal and transmitter release. Whether this occurs in layer 5 axons remains to be determined. Interestingly, in layer 4 pyramidal neurons, hyperpolarization of the presynaptic neuron was found to reduce release failures and increase synaptic currents in the postsynaptic cells (Cowan and Stricker, 2004). An amplifying role of $\mathrm{K}_{\mathrm{v}} 7$ channels in transmitter release has been observed in unmyelinated Schaffer collaterals, although these changes were observed only when axons were depolarized by elevation of external $\mathrm{K}^{+}$(Vervaeke et al., 2006). $\mathrm{K}_{\mathrm{v}} 7$ channelmediated boosting of axonal excitability has also been observed in the peripheral nervous system. Using stimulation of the peripheral myelinated sural nerves, the late superexcitability, determined by the threshold current required $7 \mathrm{~ms}$ after a maximal stimulus of the nerve, is reduced in the presence of flupirtine, a $\mathrm{K}_{\mathrm{v}} 7$ channel opener, while threshold currents were raised during the subexcitability phase after $30 \mathrm{~ms}$ (Sittl et al., 2010). These data are in accord with $\mathrm{K}_{\mathrm{v}} 7$ channel opening causing an increase in the ADP in myelinated nerves, which is known to increase in amplitude with steady hyperpolarization of the axonal resting membrane potential (Barrett and Barrett, 1982). Thus, $\mathrm{K}_{\mathrm{v}} 7$ channels may serve distinct roles in the myelinated axon by reducing the steady-state inactivation of colocalized nodal $\mathrm{Na}_{\mathrm{v}}$ channels, thereby elevating short-term axonal excitability.

$\mathrm{M}$-channels are an important target of regulation by neurotransmitters acting through $\mathrm{G}_{\mathrm{q}}$-linked metabotropic receptors, including acetylcholine (Brown and Passmore, 2009). Whether initial segment and/or nodal $\mathrm{K}_{\mathrm{v}} 7$ channels are so modulated, thereby altering presynaptic excitability, is not yet known. Our experiments focused on the primary myelinated axon. They do not rule out the possibility that more distally located channels, in axon collaterals and/or presynaptic terminals, formed either by $\mathrm{K}_{\mathrm{v}} 7.2 / 7.3$ or other subunits compositions (e.g., $\mathrm{K}_{\mathrm{v}} 7.2 / 7.5$ or $\mathrm{K}_{\mathrm{v}} 7.5$ homomers; Huang and Trussell, 2011), may also regulate local subthreshold voltage and propagating action potentials or be locally regulated by neurotransmitters. Future experiments comparing our findings with results in models of injury and epilepsy will help to illuminate the basis for the spectrum of early-onset epileptic and global development syndromes caused by $\mathrm{K}_{\mathrm{v}} 7.2$ loss of function, and will aid the effort to optimize therapeutic use of agents such as retigabine, which increase $\mathrm{K}_{\mathrm{v}} 7$ activity.

\section{References}

Adams PR, Brown DA, Constanti A (1982) M-currents and other potassium currents in bullfrog sympathetic neurones. J Physiol 330:537-572. Medline

Barrett EF, Barrett JN (1982) Intracellular recording from vertebrate myelinated axons: mechanism of the depolarizing afterpotential. J Physiol 323:117-144. Medline

Biervert C, Schroeder BC, Kubisch C, Berkovic SF, Propping P, Jentsch TJ, Steinlein OK (1998) A potassium channel mutation in neonatal human epilepsy. Science 279:403-406. CrossRef Medline

Bradke F, Fawcett JW, Spira ME (2012) Assembly of a new growth cone after axotomy: the precursor to axon regeneration. Nat Rev Neurosci 13:183193. CrossRef Medline

Brown DA, Adams PR (1980) Muscarinic suppression of a novel voltage- sensitive $\mathrm{K}+$ current in a vertebrate neurone. Nature 283:673-676. CrossRef Medline

Brown DA, Passmore GM (2009) Neural KCNQ (Kv7) channels. Br J Pharmacol 156:1185-1195. CrossRef Medline

Chagnac-Amitai Y, Luhmann HJ, Prince DA (1990) Burst generating and regular spiking layer 5 pyramidal neurons of rat neocortex have different morphological features. J Comp Neurol 296:598-613. CrossRef Medline

Chen X, Johnston D (2004) Properties of single voltage-dependent K+ channels in dendrites of CA1 pyramidal neurones of rat hippocampus. J Physiol 559:187-203. CrossRef Medline

Cooper EC (2011) Made for "anchorin": Kv7.2/7.3 (KCNQ2/KCNQ3) channels and the modulation of neuronal excitability in vertebrate axons. Semin Cell Dev Biol 22:185-192. CrossRef Medline

Cowan AI, Stricker C (2004) Functional connectivity in layer IV local excitatory circuits of rat somatosensory cortex. J Neurophysiol 92:2137-2150. CrossRef Medline

Golomb D, Yue C, Yaari Y (2006) Contribution of persistent Na+ current and M-type K+ current to somatic bursting in CA1 pyramidal cells: combined experimental and modeling study. J Neurophysiol 96:1912-1926. CrossRef Medline

Guan D, Higgs MH, Horton LR, Spain WJ, Foehring RC (2011) Contributions of Kv7-mediated potassium current to sub- and suprathreshold responses of rat layer II/III neocortical pyramidal neurons. J Neurophysiol 106:1722-1733. CrossRef Medline

Gu N, Vervaeke K, Hu H, Storm JF (2005) Kv7/KCNQ/M and HCN/h, but not $\mathrm{KCa} 2 / \mathrm{SK}$ channels, contribute to the somatic medium afterhyperpolarization and excitability control in CA1 hippocampal pyramidal cells. J Physiol 566:689-715. CrossRef Medline

Hadley JK, Noda M, Selyanko AA, Wood IC, Abogadie FC, Brown DA (2000) Differential tetraethylammonium sensitivity of KCNQ1-4 potassium channels. Br J Pharmacol 129:413-415. CrossRef Medline

Hadley JK, Passmore GM, Tatulian L, Al-Qatari M, Ye F, Wickenden AD, Brown DA (2003) Stoichiometry of expressed KCNQ2/KCNQ3 potassium channels and subunit composition of native ganglionic $\mathrm{M}$ channels deduced from block by tetraethylammonium. J Neurosci 23:5012-5019. Medline

Hallermann S, de Kock CP, Stuart GJ, Kole MH (2012) State and location dependence of action potential metabolic cost in cortical pyramidal neurons. Nat Neurosci 15:1007-1014. CrossRef Medline

Hill AS, Nishino A, Nakajo K, Zhang G, Fineman JR, Selzer ME, Okamura Y, Cooper EC (2008) Ion channel clustering at the axon initial segment and node of Ranvier evolved sequentially in early chordates. PLoS Genet 4:e1000317. CrossRef Medline

Hines ML, Carnevale NT (2001) NEURON: a tool for neuroscientists. Neuroscientist 7:123-135. CrossRef Medline

Hodgkin AL, Huxley AF (1952) A quantitative description of membrane current and its application to conduction and excitation in nerve. J Physiol 117:500-544. Medline

Hu H, Vervaeke K, Storm JF (2007) M-channels ( $\mathrm{K}_{\mathrm{v}} 7 / \mathrm{KCNQ}$ channels) that regulate synaptic integration, excitability, and spike pattern of CA1 pyramidal cells are located in the perisomatic region. J Neurosci 27:18531867. CrossRef Medline

Huang H, Trussell LO (2008) Control of presynaptic function by a persistent $\mathrm{Na}(+)$ current. Neuron 60:975-979. CrossRef Medline

Huang H, Trussell LO (2011) KCNQ5 channels control resting properties and release probability of a synapse. Nat Neurosci 14:840-847. CrossRef Medline

Hu W, Tian C, Li T, Yang M, Hou H, Shu Y (2009) Distinct contributions of $\mathrm{Na}(\mathrm{v}) 1.6$ and $\mathrm{Na}(\mathrm{v}) 1.2$ in action potential initiation and backpropagation. Nat Neurosci 12:996-1002. CrossRef Medline

Jentsch TJ (2000) Neuronal KCNQ potassium channels: physiology and role in disease. Nat Rev Neurosci 1:21-30. CrossRef Medline

Kato M, Yamagata T, Kubota M, Arai H, Yamashita S, Nakagawa T, Fujii T, Sugai K, Imai K, Uster T, Chitayat D, Weiss S, Kashii H, Kusano R, Matsumoto A, Nakamura K, Oyazato Y, Maeno M, Nishiyama K, Kodera H, et al (2013) Clinical spectrum of early onset epileptic encephalopathies caused by KCNQ2 mutation. Epilepsia 54:1282-1287. CrossRef Medline

Kharkovets T, Hardelin JP, Safieddine S, Schweizer M, El-Amraoui A, Petit C, Jentsch TJ (2000) KCNQ4, a K+ channel mutated in a form of dominant deafness, is expressed in the inner ear and the central auditory pathway. Proc Natl Acad Sci U S A 97:4333-4338. CrossRef Medline

Kole MH (2011) First node of Ranvier facilitates high-frequency burst encoding. Neuron 71:671-682. CrossRef Medline 
Kole MH, Stuart GJ (2008) Is action potential threshold lowest in the axon? Nat Neurosci 11:1253-1255. CrossRef Medline

Kole MH, Stuart GJ (2012) Signal processing in the axon initial segment. Neuron 73:235-247. CrossRef Medline

Kole MH, Hallermann S, Stuart GJ (2006) Single $I_{\mathrm{h}}$ channels in pyramidal neuron dendrites: properties, distribution, and impact on action potential output. J Neurosci 26:1677-1687. CrossRef Medline

Kole MH, Letzkus JJ, Stuart GJ (2007) Axon initial segment Kvl channels control axonal action potential waveform and synaptic efficacy. Neuron 55:633-647. CrossRef Medline

Kole MH, Ilschner SU, Kampa BM, Williams SR, Ruben PC, Stuart GJ (2008) Action potential generation requires a high sodium channel density in the axon initial segment. Nat Neurosci 11:178-186. CrossRef Medline

Lawrence JJ, Saraga F, Churchill JF, Statland JM, Travis KE, Skinner FK, McBain CJ (2006) Somatodendritic $\mathrm{K}_{\mathrm{v}} 7 / \mathrm{KCNQ} / \mathrm{M}$ channels control interspike interval in hippocampal interneurons. J Neurosci 26:1232512338. CrossRef Medline

Leão RN, Tan HM, Fisahn A (2009) $\mathrm{K}_{\mathrm{v}} 7 / \mathrm{KCNQ}$ channels control action potential phasing of pyramidal neurons during hippocampal gamma oscillations in vitro. J Neurosci 29:13353-13364. CrossRef Medline

Mainen ZF, Sejnowski TJ (1996) Influence of dendritic structure on firing pattern in model neocortical neurons. Nature 382:363-366. CrossRef Medline

Maljevic S, Wuttke TV, Lerche H (2008) Nervous system KV7 disorders: breakdown of a subthreshold brake. J Physiol 586:1791-1801. CrossRef Medline

Manning CF, Bundros AM, Trimmer JS (2012) Benefits and pitfalls of secondary antibodies: why choosing the right secondary is of primary importance. PLoS One 7:e38313. CrossRef Medline

Miceli F, Cilio MR, Taglialatela M, Bezanilla F (2009) Gating currents from neuronal $\mathrm{K}(\mathrm{V}) 7.4$ channels: general features and correlation with the ionic conductance. Channels (Austin) 3:274-283. Medline

Palmer LM, Stuart GJ (2006) Site of action potential initiation in layer 5 pyramidal neurons. J Neurosci 26:1854-1863. CrossRef Medline

Pan Z, Selyanko AA, Hadley JK, Brown DA, Dixon JE, McKinnon D (2001) Alternative splicing of KCNQ2 potassium channel transcripts contributes to the functional diversity of M-currents. J Physiol 531:347-358. CrossRef Medline

Pan Z, Kao T, Horvath Z, Lemos J, Sul JY, Cranstoun SD, Bennett V, Scherer SS, Cooper EC (2006) A common ankyrin-G-based mechanism retains $\mathrm{KCNQ}$ and $\mathrm{Na}_{\mathrm{V}}$ channels at electrically active domains of the axon. J Neurosci 26:2599-2613. CrossRef Medline

Paxinos G, Watson C (2007) The rat brain in stereotaxic coordinates, Ed 6. Amsterdam: Academic.

Poliak S, Peles E (2003) The local differentiation of myelinated axons at nodes of Ranvier. Nat Rev Neurosci 4:968-980. CrossRef Medline

Rasband MN (2010) The axon initial segment and the maintenance of neuronal polarity. Nat Rev Neurosci 11:552-562. CrossRef Medline

Robbins J, Trouslard J, Marsh SJ, Brown DA (1992) Kinetic and pharmacological properties of the $\mathrm{M}$-current in rodent neuroblastoma $\mathrm{x}$ glioma hybrid cells. J Physiol 451:159-185. Medline

Röper J, Schwarz JR (1989) Heterogeneous distribution of fast and slow potassium channels in myelinated rat nerve fibres. J Physiol 416:93-110. Medline

Safiulina VF, Zacchi P, Taglialatela M, Yaari Y, Cherubini E (2008) Low expression of Kv7/M channels facilitates intrinsic and network bursting in the developing rat hippocampus. J Physiol 586:5437-5453. CrossRef Medline

Safronov BV, Kampe K, Vogel W (1993) Single voltage-dependent potassium channels in rat peripheral nerve membrane. J Physiol 460:675-691. Medline

Sakmann B, Neher E (2009) Chapter 21. In: Single-channel recording, Ed 2. New York: Springer.

Schmidt-Hieber C, Bischofberger J (2010) Fast sodium channel gating supports localized and efficient axonal action potential initiation. J Neurosci 30:10233-10242. CrossRef Medline

Schroeder BC, Hechenberger M, Weinreich F, Kubisch C, Jentsch TJ (2000) KCNQ5, a novel potassium channel broadly expressed in brain, mediates M-type currents. J Biol Chem 275:24089-24095. CrossRef Medline

Schwarz JR, Glassmeier G, Cooper EC, Kao TC, Nodera H, Tabuena D, Kaji R, Bostock H (2006) KCNQ channels mediate IKs, a slow K+ current regulating excitability in the rat node of Ranvier. J Physiol 573:17-34. CrossRef Medline
Selyanko AA, Brown DA (1999) M-channel gating and simulation. Biophys J 77:701-713. CrossRef Medline

Selyanko AA, Hadley JK, Brown DA (2001) Properties of single M-type KCNQ2/KCNQ3 potassium channels expressed in mammalian cells. J Physiol 534:15-24. CrossRef Medline

Shah MM, Migliore M, Valencia I, Cooper EC, Brown DA (2008) Functional significance of axonal Kv7 channels in hippocampal pyramidal neurons. Proc Natl Acad Sci U S A 105:7869-7874. CrossRef Medline

Shapiro MS, Roche JP, Kaftan EJ, Cruzblanca H, Mackie K, Hille B (2000) Reconstitution of muscarinic modulation of the KCNQ2/KCNQ3 K(+) channels that underlie the neuronal M-current. J Neurosci 20:1710-1721. Medline

Shu Y, Hasenstaub A, Duque A, Yu Y, McCormick DA (2006) Modulation of intracortical synaptic potentials by presynaptic somatic membrane potential. Nature 441:761-765. CrossRef Medline

Shu Y, Yu Y, Yang J, McCormick DA (2007) Selective control of cortical axonal spikes by a slowly inactivating $\mathrm{K}+$ current. Proc Natl Acad Sci U S A 104:11453-11458. CrossRef Medline

Sittl R, Carr RW, Schwarz JR, Grafe P (2010) The Kv7 potassium channel activator flupirtine affects clinical excitability parameters of myelinated axons in isolated rat sural nerve. J Peripher Nerv Syst 15:63-72. CrossRef Medline

Sloper JJ, Powell TP (1979) A study of the axon initial segment and proximal axon of neurons in the primate motor and somatic sensory cortices. Philos Trans R Soc Lond, B, Biol Sci 285:173-197. CrossRef Medline

Stys PK, Sontheimer H, Ransom BR, Waxman SG (1993) Noninactivating, tetrodotoxin-sensitive $\mathrm{Na}+$ conductance in rat optic nerve axons. Proc Natl Acad Sci U S A 90:6976-6980. CrossRef Medline

Tatulian L, Delmas P, Abogadie FC, Brown DA (2001) Activation of expressed KCNQ potassium currents and native neuronal M-type potassium currents by the anti-convulsant drug retigabine. J Neurosci 21: 5535-5545. Medline

Thomas RC (1972) Electrogenic sodium pump in nerve and muscle cells. Physiol Rev 52:563-594. Medline

Urbani A, Belluzzi O (2000) Riluzole inhibits the persistent sodium current in mammalian CNS neurons. Eur J Neurosci 12:3567-3574. CrossRef Medline

Vervaeke K, Gu N, Agdestein C, Hu H, Storm JF (2006) Kv7/KCNQ/Mchannels in rat glutamatergic hippocampal axons and their role in regulation of excitability and transmitter release. J Physiol 576:235-256. CrossRef Medline

Wang HS, Pan Z, Shi W, Brown BS, Wymore RS, Cohen IS, Dixon JE, McKinnon D (1998) KCNQ2 and KCNQ3 potassium channel subunits: molecular correlates of the M-channel. Science 282:1890-1893. CrossRef Medline

Wang HS, Brown BS, McKinnon D, Cohen IS (2000) Molecular basis for differential sensitivity of KCNQ and I(Ks) channels to the cognitive enhancer XE991. Mol Pharmacol 57:1218-1223. Medline

Waxman SG, Kocsis JD, Stys PK (1995) The axon. New York: Oxford UP.

Weckhuysen S, Mandelstam S, Suls A, Audenaert D, Deconinck T, Claes LR, Deprez L, Smets K, Hristova D, Yordanova I, Jordanova A, Ceulemans B, Jansen A, Hasaerts D, Roelens F, Lagae L, Yendle S, Stanley T, Heron SE, Mulley JC, et al (2012) KCNQ2 encephalopathy: emerging phenotype of a neonatal epileptic encephalopathy. Ann Neurol 71:15-25. CrossRef Medline

Wickenden AD, Yu W, Zou A, Jegla T, Wagoner PK (2000) Retigabine, a novel anti-convulsant, enhances activation of KCNQ2/Q3 potassium channels. Mol Pharmacol 58:591-600. Medline

Williams SR, Wozny C (2011) Errors in the measurement of voltageactivated ion channels in cell-attached patch-clamp recordings. Nat Commun 2:242. CrossRef Medline

Yue C, Yaari Y (2004) KCNQ/M channels control spike afterdepolarization and burst generation in hippocampal neurons. J Neurosci 24:4614-4624. CrossRef Medline

Yue C, Yaari Y (2006) Axo-somatic and apical dendritic Kv7/M channels differentially regulate the intrinsic excitability of adult rat CA1 pyramidal cells. J Neurophysiol 95:3480-3495. CrossRef Medline

Zagotta WN, Hoshi T, Aldrich RW (1994) Shaker potassium channel gating. III: evaluation of kinetic models for activation. J Gen Physiol 103: 321-362. CrossRef Medline

Zhang X, Bennett V (1998) Restriction of $480 / 270-k D$ ankyrin G to axon proximal segments requires multiple ankyrin G-specific domains. J Cell Biol 142:1571-1581. CrossRef Medline 